\title{
Second Prize Essay
}

\section{Commander Harry Jone "Sans Pareil" R.N., H.M.S.}

To cite this article: Commander Harry Jone "Sans Pareil" R.N., H.M.S. (1900) Second Prize Essay, Royal United Services Institution. Journal, 44:267, 491-543, DOI: 10.1080/03071840009420005

To link to this article: http://dx.doi.org/10.1080/03071840009420005

$$
\text { 曲 Published online: } 11 \text { Sep } 2009 .
$$

Submit your article to this journal 4

Џll Article views: 4

Q View related articles $₫$ 


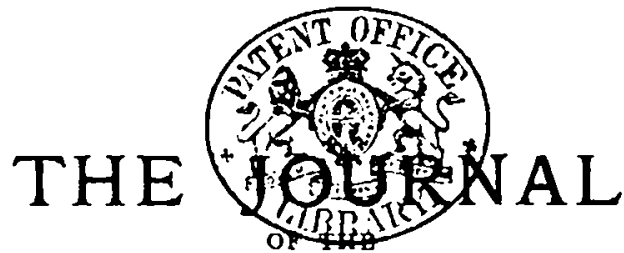 \\ ROYAL UNITED SERVICE INSTITUTION.

Vol. XLIV. HIAY; 1900. No. 267.

[Authors alone are responsible for the contents of their respective Papers.]

SECOND PRIZE ESSAY.

\section{Subject:}

" Considering the Changes made in Naval Construction duking the Past Twesty Years, and in View of the Experiesce gained during the ChINo-JapaNese aNd SPANish-AMERICaN Wars, what are the Best Types of War-V'essels for the British Nayy, ixcluding Armour, Akmanent, and General EqUIPMENT FOR SHIPS OF ALL Types?"1

By' Commander HARRY JONES, R.N., H.MI.S. "Sans Paril."

"Non omuia possumus. omnes.

\section{INTRODUCTION.}

IN order to fully conside what are the most efficient types for the British Navy; it will be necessary to examine briefly what will be the cluties required of our Navy in war with a first-class naval Power, and the nature of the vessels necessan to perform these duties with success. This bcing donc, we can proceed to a detailed discussion of the requirements of each class in turn, and so arrive at some approximation of the best type in each class.

To maintain the command of the sea, which in war is essential to our existence as a great nation, it is absolutely necessary that we should have a fleet of fighting-ships of such strength as to be able to engage any possible enemy with something more than a reasonable prospect of

i References :-

Appendix to Report of the Chief of the Bureau of Navigation-Wrashington, 1898. (Referred to herein as the Official Report.)

"Brasscy's Naval Annuals."

Journals of the R.U.S.I.

"Armour and its Attack by Artillery."-Orde Brow"ne.

VOL. XIIT. 
success. In the wars of the French Revolution our line-of-battle ships were of sufficient strength and-number to ensure our not being at a disadvantage with our encmy in this respect, and proved themselves thoroughly equal to the task required of them. Our battle-ships of to-day will have the same róle to play in war, and no superiority in cruisers, however well designed or armoured, can possibly make up for a deficiency in battle-ship strength. Cruisers are not less essential in their own sphere, which comprises the duties performed so well by their predecessors, the sailing frigates of days gone by-duties which practically could not be performed by either line-of-battle ships, or heavy armoured vessels. So far, then, we see the requirements for our fleet of to-day present a great similarity to the requirements of the past.

The introduction of torpedoes, and the development of torpedo-boats and destroyers has, however, brought in a new element. It is true that torpedo-vessels have been compared to the fire-ships of former days; but the comparison is not complete, the fire ships having been so deficient in that mobility which is the chicf characteristic of torpedo-boats. The influence of torpedoes on naval war has certainly been against the interests of this country. With our undoubted superiority in shipbuilding resources, we should now be in a much stronger position at sea, were it not for the uncertainty produced by the introduction of these weapons, and this for the following reasons:-In order to maintain the command of the sea, it is more absolutely imperative to us than to our foes to keep ships at sea at all times, and thus rendering them more liable to torpedo attack. In short, we shall be more generally in the position of defence than attack in torpedo matters, and shall therefore stand to lose more. A successful torpedo attack, difficult though it may be to achieve, would produce a moral effect of a very far-reaching character, and would do much to neutralise a superiority in battle-ship strength. Torpedoes are now a factor in naval war which must be reckoned with; and that our naval authorities are fully alive to this, needs no further proof than the enormous defensive works now in progress at Portland, Gibraltar, and other strategic points, and the construction of the large number of destroyers which has taken place in recent years.

The experience of peace manœuvres seems to show that the best method of defeating the attacks of torpedo-boats on a fleet at sea, is to employ a large number of vessels of the destroyer class having a very high speed, and better gun power than the ordinary torpedo-boat, to watch for and defeat them before they get within range of the battle fleet. These destroyers are themselves armed with torpedoes to be used if opportunity offers, but the primary object is the attack of the enemy's. boats and not his ships. The construction of the torpedo-boat proper in our Navy has now practically ceased, and all torpedo-vessels building are of the destrojer class.

In these few brief remarks, I have endeavoured to indicate that the ships of our fighting Navy are necessarily divided into three classes, and that, with very few exceptions, every new yessel built belongs definitely to 
one of them. I have then divided this essay into three parts, devoted to the discussion of :-

1. Battle-ships.

2. Cruisers.

3. Torpedo-vessels.

Each part is divided into chapters dealing with the various requirements and qualifications for an efficient vessel of the class under discussion, and I have, as far as possible, tried to show how the ships of to-day have been developed from their predecessors of twenty years ago, and to point out the improvements and modifications which appear desirable, in view of the experience gained in the Chino-Japanese and SpanishAmerican Wars.

\section{PART I.-BATTLE-SHIPS.}

\section{Chapter I.}

\section{The Defensive Qualities of Battle-ships, including Armour,} Conl Protection, and Water-tight Sub-Division.

The demand for armour protection was in the first instance caused by the destructive effect of direct shell fire, as demonstrated at Sinope, and off Sebastopol. To meet this demand for protection against shell fire, the floating batteries and early ironclads were constructed. Against the guns of that day the armour of these vessels was undoubtedly very efficient, but what is most worthy of remark is, that the armour-plates were used chiefly to protect the batteries of guns, with their crews, not to protect machinery or buoyancy, as we shall see was the case in later vessels. The inevitable consequence of this introduction of armour was to produce guns and shells to penetrate it, and from this time on began the rivalry of constant increase in the size and power of the gun, and corresponding increase of thickness in the armour-plates. This rivalry had two immediate effects. The increase in gun-power necessitated a decrease in the number of guns, and ships were constructed mounting so few as four very heavy guns. The increase in thickness of armour involved a decrease in the area which could be defended. These considerations produced in the British Navy the turret-ships "Devastation," "Thunderer," and "Dreadnought" - an admirable type under the conditions then existing. 'They hatl four very heavy guns, and, by reason of their very low free-board, a comparatively small area of armour was required, and this was provided sufficient to meet the attack of any but the largest guns of that day. The armour extended not only over the guns' crews, but also over the water-line for the entire length of the vessels. They were also provided with a 3-inch steel deck at the upper level of the armour. The "Dreadnought" has always been considered a good type of fighting-ship by naval officers, but was at a disadvantage in having no secondary armament. Her defensive powers were decidedly good, but the slow rate of firing of her four heavy guns does not give her, for the present day, sufficient powers of attack. It may be noted, while spcaking of these 
ships, that the "Nile" and "Trafalgar" were built fifteen years later on very similar lines. A sccondary battery of six guns was added, and the armour gencrally thickened to meet the altered conditions of guns. To do this a small part of the water-line at each end was left unprotected, and the displacement was increased by 1,100 tons. These two ships, like their predecessors, are stronger in defensive powers than offensive, the secondary armament consisting of only six 6 -inch (formerly $4 \cdot 7$-inch), against the ten 6 -inch of the "Royal Sovercign." Nevertheless, they are the best battle-ships built before that class.

Owing to further increase of size and improvements of design in naval artillery after the completion of the " Dreadnought," a great increase in the thickness of the armour plates was again necessary to meet the attack of the Palliser projectiles designed for armour attack. To provide for the increased weight of armour plates, there were two courses open, viz., to increase the displacement of the ships, or to reduce the area defended. The latter plan was adopted, and it at once became necessary to decide what parts of the ships were most important to protect, and what should be left undefended. As secondary batteries of medium guns at that time were either not provided at all, or 'only considered of very' minor importance, the armour was devoted to the provision of a strong central citadel, protecting machinery and boilers, and also the loading arrangements of the heavy guns, which were mounted in turrets placed en échelon above the citadel. The citadel extended less than one-third the length, and outside its limits the ships were entirely. unarmoured. To prevent sinking by the gun-fire on the unarmoured ends, there is an armoured deck below water-line, water-tight sub-divisions, and cc fferdams packed with cork The examples of this type are the "Inflexible," "Ajax," "Agamemnon," "Colossus" and "Edinburgh." In order to carry out the design, the ships were necessarily of great beam and short length, consequently bad steamers and hard to steer. Owing to the disposition of the heavy guns, it was not possible to mount a satisfactory secondary armament, and such guns of medium size ar have been put in scem to have been mounted quite as an after-thought on the superstructure, are cntirely unprotected, and with exposed and difficult ammunition supply. The concentration of the armour on a central citadel leaving a very large proportion of the ship quite unprotected and open to light gun attack, a demand arose at once for the provision of a battery of medium guns for the attack of the' unarmoured ends, and, at the same time the speed and steering of the central citadel ships being so unsatisfactory, it was considered necessary to design future ships of finer lines and greater engine-power.

These considerations produced the "Admiral" class, in which, as the machinery and boilers occupied greater space, the belt was necessarily of greater length, and the unarmoured ends not so long in proportion. On the other hand, the depth of the belt was much less, and only extended from about two feet above the water-line to five feet below. The barbettes and armoured hoists for the ammunition afford-good protection for all the mechanism of the heavy guns, but the beams and bulkheads 
supporting the barbettes are entirely unprotected. The only protection afforded the secondary battery is that of the transwerse armoured bulkheads at either end.

In the "Sans Pareil," the secondary battery, which has double the number of guns, is protected by 3 -inch stecl plates on the side. The turret is also mounted above an armoured redoubt, and therefore has not the defect of an unprotected base like the barbettes of the "Admirals."

In this brief resume of the armour protection of these ships, which are now fast becoming obsolete, I frave endeavoured to show the general tendency which the increasing power of the gun produced on the distribution of armour: a tendency, namely, to protect the engines and boilers at the expense of both the defence of the guns and their crews, as also of the reserve buojancy of the ships. This tendency reaches its climax in the "Colossus" and "Admiral" classes, after which the pendulum seems to have swung back, and in each successive design we shall see increasing importance attached to the secondary armament and its protection.

In considering how a given weight of armour may most profitably be distributed, we must bear in mind that the three points most necessary to protect are:-

1. The propelling machinery:

2. Buoyancy and stability.

3. Gun-power and supply of ammunition.

If any one of these three points be neglected for the benefit of the other two, it will invite the enemy to concentrate his attack on the weak spot, and use the projectiles best suited to that end. While the English constructors of this period seem to have attached the greatest importance to the protection of machinery, the French seem always to have preferred protecting the water-line. 'Both neglected the unfortunate guns' crews of the secondary battery; yet a ship could as certainly be put out of action by the killing and wounding of large numbers of men-added to the disorganisation and destruction wrought by the fires which are certain to occur in the unarmoured parts, necessitating the withdrawal of men from other duties to extinguish them-as by disabling of machinery or destruction of buoyancy. Happily this state of things is now passed as regards our own Navy, and we see a due balance given to all the three considerations in the armouring of modern battle-ships. That the constructors have been aided in this by the inventions of Harvey and Krupp, is not to be denied, but they were on the right road to meet the requirements of the present when the "Rojal Sovercign" class was built, with compound armour only.

Continuing our review of armour in British battle-ships, we come next to the "Royal Sovereign" class. In these magnificent ships we find the water-line protected for about two-thirds the length by 18 -inch compound armour, an armoured deck 3 inches thick being laid at the upper edge of this belt. Ample protection is thus given to engines, boilers, and magazines, against everything but armour-piercing shot from the heavicst guns, and these will only penetrate when fired at comparatively short 
range and nearly normal to the armour plates. The heavy gun positions, with their hydraulic machinery and ammunition supply, are also amply protected by 17 -inch compound armour. The comparatively short unarmoured ends are provided with an armoured deck extending from the lower edge of the side armour, and are, of course, well sub-divided by water-tight bulkheads. Above the 18-inch belt armour, and extending up to the next deck, is 5 -inch armour, which would at least prevent any shell from a 6 -inch gun bursting behind it. Four of the 6 -inch guns are mounted in armoured casemates, placed with 6 -inch compound armour in front and 2 -inch in rear.

The value of this system of casemate protection, which has now been adopted in all our ships, requires some discussion as against the system of mounting the guns in an armoured battery:

The objections to the casemates are as follows:-

1. Although the guns are very efficiently protected, there are large spaces outside which will be open to destruction and fire by common shell.

2. The protection in rear being comparatively thin, the guns on the disengaged side will be more liable to injury than guns in a battery.

3. The guns being isolated will be more difficult to control.

As regards the first point the reply is, that the available weight for protection being limited, and the guns being infinitely more important to protect than the unoccupied spaces outside the casemates, the protection of these has been wisely sacrificed. By the abolition of wood and all inflammable material in the unarmoured parts, the need of such protection is also reduced in vessels now building. The second objection appears at first sight a serious one, but it must be remembered that before any' projectile strikes the rear face of a casemate it must already have passed through the opposite ship's side, and consequently, if a shell, have been exploded, and against the fragments of any exploded shell the 2-inch bulkhead should be ample protection. The difficulties of control on account of the isolation of the different guns can be overcome by organisation and training, and any objection on this score is far out-weighed by the advantages gained.

'The chief advantage of the casemate system is the localisation of the effects of shell fire. A shell bursting in one casemate can have no effect upon the guns and men in the others. On the other hand, a shell bursting near one gun in a battery, besides the physical damage which it might cause to men at other guns, would certainly have a very great moral effect there. It is also probable that the gases generated by a shell explosion will greatly impede work at all the guns of a battery.

The remaining six 6 -inch guns of the "Royal Sovereign" are mounted on the upper deck and only protected by shields. This has been altered in the "Magnificent" class, as the value of the casemate system came to be more appreciated. 
In the "Royal Sovereign" class, we find a truer appreciation of the conditions of modern naval war than in any previous ship. We cannot guard against everything, and go into battle in perfect safety, but here we see no particular quality given undue prominence, and an endeavour made to give each part of the ship its fair measure of protection in view of its importance to the whole. It being granted that the three points chiefly necessary to defend are those $I$ have stated in a previous paragraph, viz.:-1. Notive power. 2. Buoyancy and stability. 3. Gunpower and ammunition supply;-it now becomes necessary to decide against what size and nature of projectiles we are to provide armour in each of these three cases. The most logical way of setting about the task would seem to be somewhat as follows :-

1. Consider what guns your most probable enemy is mounting in his most recent ships.

2. Decide what calibre of enemy's guns you propose to defend each part of your ship against, and whether you will defend it against armour-piercing projectiles or only against common shell.

3. Having decided the gun-power against which you wish to protect each part, you have now to decide how you will effect your purpose, whether by vertical armour, deck plating, or a combination of both.

For instance, suppose it to have been decided that a new battle-ship is to have her machinery, and heavy guns with their machinery, protected against the French 12 -inch gun firing A.P. ${ }^{1}$ shot, that the medium guns and their ammunition supply be protected against the same gun firing common shell, and the 5.5-inch firing A.P., the constructor would then have three definite requirements to meet, and would make his arrangements accordingly.

In the "Najestic" class it would appear that the problem has been set and answered somewhat on these lines. The French 12-inch gun is capable of penetrating 28 inches of wrought-iron up to 2,000 yards by Tresidder's formula: The 14-inch Harveyized armour on the "Niajestic's" barbettes should be about equal to 28 inches iron, and when the difficulty of hitting the curved surface normally is considered, these barbettes may be said to be a match for the French 12 -inch gun. Next, taking the 9 -inch armour on the ship's side. This, of course, could not be expected to defeat the 12-inch A.P. shot at moderate range, but if such a projectile did penetrate, it would most certainly be kept out of the engine and boiler rooms by the armoured deck (four inches on the slopes and two inches on the flat), which would cause the projectile to glance. This 9 -inch armour would cause any common shell to burst outside the ship, and would probably kecp out ail A.P. below the 27 -centimetre size, and these also when striking at all obliquely. It is difficult to say if the 6 -inch casemates would be capable of resisting a common shell from 12-inch guns. Common shell are now being made of steel, with a sharp point, and their capabilities are not fully known, but it seems probable that the casemates are about equal to the work. They should certainly 
be proof against armour-piercing shot from the French $5 \cdot 5$-inch, which is generally: mounted"as a medium gun in the French ships. There remains the question of the unarmoured ends, and here a 3 -inch steel deck is worked below tho water-ine, which would certainly deflect any but the very heaviest armour-piercing projectiles under ordinary conditions.: The loss of buoyancy' which would be caused by hits on the unarmoured part of the water-line is limited, as far as possible; by this armoured deck and the sub-division into water-tight compartments.

Before leaving the "Majestic," it would be as well to notice the points in which the "Royal Sovereign" has been improved on. Firstly, all the.6-inch guns have been placed in casemates, and there are twelve of them instead of ten. The improved Harveyized steel has, enabled the constructor to reduce the thickness of plates used, and increase the area defended, so that the side is protected by 9 -inch plates from the maindeck to well below the water-line. The armoured deck over the central part of the ship being taken to the bottom of the belt insteal of to the top, as in the "Royal Sovereign;". effectually makes up for any want of protection the engine-room might suffer from the reduction of the belt armour from 18-inch compound to 0-inch Harveyized steel. . This alteration in position of the armoured deck is the most important difference in design between the two vessels. In combination, with the extensive 9-inch side armour, it secms a most admirable device for protecting the machinery: against all projectiles, and a large part of the ship against all common and moderate-sized A.P.

As at the time when the "Royal Sovercign" class were designed, two ships of smaller dimensions, the "Barfleur". and "Centurion," were also laid down, so, when the "Majestics" were built; a battle-ship on the same lines, though possessing less power, offensive and defensive, was designed in the "Renown," which has 10 -inch guns instead of the 12-inch of the "Majestic," and somewhat thinner armour. - This policy of building a few.battle-ships of somewhat smaller dimensions we see again carried out in the construction of the six 'ships of the "Canopus" or the improved "Renown" class-2,000 tons smaller than the "Formidables" or improved "Majestics." It will be noticed that all these ships of the smaller class are designed with a draught of water fitting them to pass the Canal. They are all of high speed, and carry large quantities of coal, to which qualities offensive and defensive powers have in a certain measure been sacrificed. In the case of the "Canopus" the sacrifice scems to be almost entirely one of armour and structural strength, her gun power being very nearly equal to that of the "Formidable." The raison d'tere of all these smaller vessels seems to be to enable England to concentrate a powerful-flect in the Far East. While distinctly inferior in fighting qualities to the bigger ships, they are powerful enough offensively and defensively to cope with anything in foreign. Navies capable of passing the Canal, and would be strong enough to render -very efficient service in the line of battle in European waters againsẗ any modern flect; although it must be admitted that here their lighter armour would place them at a disadvantage compared with the ".Majestic" and "Formidable." 
The "Formidable" and "Canopus" class have their guns arranged similarly to the "Majestic." The side armour is 9-inch in the "Formidable," against 6 -inch in the "Canopus." The barbette armour is 12-inch in each case. The armoured deck is only $2 \frac{1}{2}$ inches thick in the "Canopus," against 4 inches and 2 inches in the "Formidable." A second armoured deck, 1 inch in thickness, is worked in both ships.at the level of the main deck. The bows are protected by 2 -inch nickelstecl plates at the water-line, thus protecting the buoyancy against light shell fire.

In this short account of the development of armour protection in these typical ships of the British Navy, a few points should be noticed.

1. The denand in the first instance, based upon experience in acar, was for protection for the guns and crews against shell fire.

2. In times of peace, and by reason of the constant advance made in the power of artillery, the true nature of this demand became overlooked, and too great importance was attached to the defence of buojancy and machinery, and too little to the protection of the men, without whom the most unsinkable ship is but at helpless $\log$ upon the watcr.

3. A truer appreciation of the necessities of the case is shown in the design of the "Royal Sovercign" class, and in later ships we see even still greater importance attached to the defence of the guns' crews of the sccondary battery. Nothing has: been shown more clearly: in the late Spanish-American War than that; as a general rule, ships will not be put out of action by disablement of machinery, or sunk by gun fire, but will usually be defeated by the damage wrought by shell firc on the batteries and exposed parts. The water-line will always be difficult to strike, except by a lucky shot, but a good captain of a gun should have little difficulty in striking the hull of a ship at all moderate ranges.

It is now necessary to make some short review of the armouring of ships of forcign nations, pointing out in what they differ from our own designs.

French battle-ships have been almost invariably designed with a complete belt, thicker over the machinery than at the ends. The heavy guns have generally been protected to a certain extent, though perhaps not so well as in our own ships. The secondary batteries are generally not so well protected as in our ships of the same date. For instance, the "Marceau," contemporary to the "Admiral" class, has an entirely open and unprotected battery. The "Admirals" have at least a transverse bulkhead at each end, which would be a most valuable protection when approaching or retreating from an enemy. Again, the secondary" battery of the "Charlemagne" is only defended by 3 -inch armour, a protection which compares very unfavourably with the 6 -inch casemates in British ships of the same date. Not the least amongst the effects of shell explosion between decks will be the choking and blinding smoke which will be produced. Our guns, separated from each other as they are, should certainly be better off than the crowded French batteries in this respect. Our ships have frequently been criticised for their want of water-line protection, and for this have generally been unfavourably compared with the French, but any disadvan- 
tage they may have in this particular is amply conpensated for by the greater protection afforded to the auxiliary armament by bulkheads or casemates.

We find Italian battle-ships constructed on three distinct plans. Firstly, the contenıporaries of our "Inflexible," which have a very heavily armoured central citadel with no protection for secondary armament, and only armoured deck protection for the ends. Of this type are the "Dandolo," "Duilio," and "Andrea Doria" class. Secondly, the "Italia" and "Lcpanto" in which the water-line is only protected by an armoured deck, the heavy guns and bases of the funnels being heavily armoured, and the secondary armament entirely unprotected. These ships are of very large dimensions, but cannot be considered a good type of battle-ship in any way, on account of their lack of vertical armour protection. The "Sardegna" and her sisters are a compromise between these two classes - the heavy gun positions being heavily armoured and the central citadel protected by 4 -inch armour only, the ends being unarmoured. Thirdly, we find the Italians building ships in which an attempt has been made to combine the advantages of both English and French schools on a moderate displacement. Examples of this class are the "St. Bon" and "Filiberto," of 9,800 tons, which have a belt of $9 \frac{3}{4}$ inches to 4 inches; heavy gun positions being defended by $9 \frac{3}{4}$ inches, and secondary battery by armour 6 inches in thickness. Also the smaller armoured cruisers " Varese," of 6,700, and "Vettor Pisani," of 6,500 tons, having a 6 -inch belt and 6 -inch armour over their heavy guns and secondary battery. One of these, the "Giuseppe Garibaldi," was sold to Spain and accompanied Admiral Cervera to Santiago under the name of the "Colon," being defeated and driven ashore by the American flect and scuttled by her own crew. The "Colon" left Spain without her heavy guns, which were not ready, but in the matter of armour she seems to have been thoroughly satisfactory. She was not set on fire, as were all the three other ships, and there seem to have been no internal explosions, nor does she seem to have been greatly damaged by gun firc in any way. (Tide Official Report, pp. 589-590.) The "Colon" suriendered, ran ashore, and was scuttled by the Spaniards because escape was impossible, and they did not wish to make their enemies a present of such an efficient ship. The battle of Santiago is a most convincing proof of the superiority of a vessel defended like the "Colon" by a large extent of thin armour over ships having thick beit and barbette armour only. The "Vizcaya" and her sisters were completely defeated by shell fire nearly two hours before the "Colon" was driven ashore, and though this is to some extent attributable to the superior speed of the latter, it is chiefly due to the fact that her armour protection was applied on more correct principles.

In Germany recent battle-ships have a complete belt of moderate thickness. In the " Kaiser Friedrich III.," for instance, the thickest plates are $11 \frac{3}{4}$ inches. The guns are well protected and isolated, but the advantage of the complete belt is paid for by leaving all the ship's side unarmoured except at the gun positions. The machinery too is probably not so well protected as is that of the "MIajestic." The armour is undoubtedly disposed on a carefully considered system, but whether a 
better one than the British must remain largely a matter of opinion. The injuries suffered by Chinese and Spanish ships point rather to the superiority of the British designs, in my estimation.

Russia, in her more recent ships, has inclined to the English system of armouring (e.g., "Sissoi Velikie" and "Tria Sviatitelia"), with the exception of the secondary batteries, the guns of which are not isolated, but are protected by 5 -inch armour on the ship's side.

The United States have leaned to the British sy'stem in all their new ships, but without slavish imitation of us, as they have introduced many new features. In the "Oregon" class particularly" we see the side armour carried high up, the ends left undefended by side armour, and all gun positions isolated and well protected. The differences consist in the lower freeboard and the mounting and number of guns $\rightarrow$ not in the principles on which the armour has been applied.

'The Japanese have had built in . England two ships of 12,000 tons, the "Fuji" and "Yashima," and are now having three larger ones of about 15,000 tons. In the "Fuji" the armour is distributed on the same principles as in the " Royal Sovereign," and in the ships now under construction the "Majestic" design has been adopted, except that the belt armour is continued to the ends with a reduced thickness; the Japanese evidently desiring to obtain the advantages of both English and French plans. The opinions of the Japanese are entitled to great respect by reason of the valuable experience they obtained in their war with China, and it is quite evident that they fully appreciate the necessity of dispersing their guns, and protecting them against shell fire, but they are not prepared to go so far as our own constructors in leaving the water-line unprotected at the ends.

Having thus reviewed the application of armour to modern battleships, particularly for the British, and briefly for foreign, ships, we find that while the policy of the British constructors has been to isolate the guns' crews and localise the effect of shell fire as far as possible, at the same time protecting machinery and heavy guns with thick armour, and leaving the water-line for a small part of its length at the ends unarmoured, the French constructors invariably provide a complete belt, which must be at the expense of the guns' crew to some exient. The other nations of the world we find applying armour to their ships on different plans, between these two extremes endeavouring to obtain the advantages of both. War can alone decide definitely which is absolutely the best design, and the lessons of the two wars we are asked to consider seem undoubtedly to point in favour of the designs of our constructors rather than those of France. The Japanese, with their late experiences, have undoubtedly inclined rather to the British design than to the French.

$M y$ conclusion is that the British system is on the whole the best, but it might be advisable so far to modify it as to protect the waterline at the bows (not the stern) with plates to defeat light shells from, say, 12-pounder Q.F. guns. This is now being done in "Canopus," "Formidable," and latest designs. 
In this discussion of armour protection, I have so far omitted all mention of the conning-towers. These are, and must be, provided in all ships, and there is also generally an alternative position defended by comparatively light armotir, and provided, like the main conning-tower, with stcering wheels and telegraphs. A few years ago the conning-tower of a battle-ship was a most bewildering place to look at ; besides the wheel and telegraphs, it contained the directors and firing keys for both guns and torpedocs, and a mass of voice-tubes and electric bells, the working of which would be most confusing and distracting to the captain in action. Much of this has now been simplified or swept away. Guns are no longer fired by directors, and the only voice-pipe, except those to engine-rooms, goes to a central exchange, whence all messages are transmitted by other voice-pipes to their destination. Telegraphs, wheel, and torpedo directors are necessarily retained. All these changes are for the better, and enable the constructor to reduce the size of the conning-tower, and so make it a smaller target. The captain, navigating officer, midshipman at voicetube, and quarter-master at the wheel, need be the only occupants, the navigator firing the torpedoes, if opportunity occur.

The alternative conning-tower is usually very lightly armoured, and contains 'wheel, telegraphs, voice-pipes, and directors for after torpedoes. The advantage of the alternative conning-tower is questionable; the position for conning must necessarily be poor, and the light armour is not much protection against the destruction of the shafting of the wheel and telegraphs by shell fire. If this shafting were coupled up before action, its destruction would probably jam the wheel or telegraph in'the main position ; if left disconnected, as it should be, till the main conning-tower is disabled-even supposing the alternative gear still remained intactthere would probably be considerable difficulty and loss of time in coupling it correctly to the main shafting. I would advocate that there should be no alternative wheel or telegraphs on deck, but that these should be placed where they would be protected by the belt armour immediately below the conning-tower, and also at the steering engine itself.

$\mathrm{U}_{\mathrm{p}}$ to the present it has not been considered necessary to afford any armour protection to the light Q.F. guns mounted on the upper deck and in the fighting tops. The primary use of light Q.F. guns is to defeat the attack of torpedo-boats, and for this armour protection is not required, unless the torpedo-boat attack be delivered during a fleet action. These guns, however, would be of considerable use in attacking the unarmoured portions of the enemy, and some measure of protection to their crews would be of great value. The 6-and 3-pounders are usually protected with light shields, but the use of these is now generally condemned. They are only effective against rifle fire, and would serve to burst shell which might otherwise have passed clear of the guns' crews. If protection against the shell fire of light guns of corresponding calibre cannot be afforded with, say, 2-inch nickel-stecl plates, it would appear better to have these guns mounted as clear as possible of any thin plating or shields, which would only serve to burst shell amongst the men. For one ton weight, 27 square feet of plate, 2 inches thick, could be pro- 
vided. It would seem worth while to put two or three tons of such plating over each of the "Majestic's" 12-pounders, and that the extra weight would be very well expended.

In addition to the protection afforded by armour plates, the coal bunkers are generally arranged to afford some additional protection against gun-fire. Coal has considerable stopping power, two fect of it being roughly equivalent to 1 -inch iron. ${ }^{2}$ It has generally hitherto been considered proof against ignition by shell fire, as it was not fired during the experiments carricd out in $\mathbf{1 8 8 0 .}$

However, in the late Spanish-American war, coal on board the "Maria Teresa" was fire 1 by a 5-inch shell bursting in the bunker. (Sce photo in the Official Report, etc.) Whether coal is fired by shell explosion or not probably depends largely on the nature of the coal, the amount of coal in the bunker, and if the bunker is liable or not to draught. A bunker half full of dusty coal open to ventilation would be a very different thing to a bunker tightly packed with coal in large lumps and not open to the air. Coal can, of course, only be regarded as an auxiliary defence, and as its principal use is for the motive power of the ship, no considcration of defence should be allowed to cause the bunkers to be so placed as to interfere with the steaming efficiency, or even to make the work of coaling ship a very lengthy operation. In the later types of battle-ship we find the coal-bunkers disposed behind the belt armour, above and below the armoured deck, abreast of the boilers and engines. This would seem to be a wise and proper disposition from all points of view ; as the powerful belt will defeat everything but armour-piercing shot; the coal will not be liable to be fired by shells, and will form a not inconsiderable addition to the strength of the belt defence against heavy armour-piercing projectiles.

Continuing our review of defensive' propertics of battle-ships, we next come to the sub-division of the ship into water-tight compartments, and we may remark, in passing, that unless our ships werc really well provided in this respect, it would be impossible to justify the British system of leaving the water-line at the ends comparatively unprotected. The system of division into double bottoms, wings, and comparatively small compartments, throughout all that part of the ship below water, is the answer of the constructors to the development of the torpedo and the ram. As battle-ships are now constructed, if the compartments are properly closed, a single explosion of a torpedo should not sink her, though she would, of course, be disabled and have to dock for repairs. Against the ram also, the ship, though disabled, might be kept afloat in many cases. The case of the unfortunate "Victoria" will, of course, occur to everyone in this connection, but the "Victoria" was not well subdivided to begin with, and being caught unprepared, a great many doors which would be closed in action were open. (N.B.-Extra bulkheads were put in the "Sans Pareil" after the disaster.) The high freeboard also of the modern battle-ship, giving a large reserve of buojancy, helps to save her from sinking so quickly after being rammed, as did the "Victoria." 
The water-tight compartment system has saved many oi our ships which have had the misfortune to take the ground-a misfortune which will be all the more likely to occur in war-time, when ships will have to work on an enemy's coast without the help of lights and buoys.

Our ships are now very minutely sub-divided into compartments, and the value of this cannot be over-rated when we consider the dangers of torpedoes, ram, and rocks. A ship with a flooded compartment might, in war-time, be docked, patched, and out to sea again in a few days, which without the water-tight division would have been a total loss. This sub-division by bulkheads, which adds materially to the structural strength of the hull and its defensive power, is a quality which does not meet the eye so readily as a very large number of guns, or very high speed in a ship of moderate dimensions; but the ship cannot be well divided without a large expenditure of weight, and I have no doubt that one very great reason why our ships seem to fall behind those of other nations of the same size in the matters of gun-power and speed, is that they are divided into a greater number of compartments.

The water-tight division of our ships complicates very much the communications and working of the ship in action, and in the battleships of ten years ago many most important doors and hatches had to be kept open to keep up the ammunition supply, also to admit of the escape of men stationed in the lower parts of the ship. In recent ships all this has been most carefully thought out. The ammunition is carried from its magazine along passage way3, which are well inside the body of the ship under the armoured deck, and well protected against injury; from the passage way it is taken by ammunition tubes direct to the guns. Escape trunks are led from all spaces below water-line which are not readily accessible, and where it is necessary to keep men stationed in action. By this means a much larger proportion of doors can be kept closed without militating against an effective supply of ammunition, or shutting men in confined places without a chance of escape should the ship sink.

To complete our review of defensive properties, we have now to consider the question of cofferdams, packed with cork or other material, for the protection of the unarmoured ends and openings in the armoured deck. Cork-packed cofferdams are used in the "Inflexible" type in our Navy, and cofferdams to be packed with canvas and other material in war are in very general use in most of our ships. Many attempts have been made to obtain some water-excluding material with which to protect the buoyancy of ships against the effects of light gun-fire. America especially is devoting much attention to the subject, and a material called "corn-pith cellulose" is now much used. According to the trials described in "Brassey's Naval Annual," 1890, p. 364, this material, packed under pressure, is capable of closing up a hole made by an 8-inch shot. I believe, however, that when tried in this country the results were by no means successful. It must be remembered that packing of this description in large quantities makes no small addition to the weight of a ship, and that it can have but very little effect in stopping a projectile, however valuable it may be as a leak-stopper when the projectile has passed. 
Could efficient water-excluding packing, however, be provided at a moderate weight, it should certainly be made use of. An unpacked cofferdam, of course, facilitates the work of stopping a shot hole, as it should not be difficult to fill it up and so make use of the water pressure in stopping the hole in the inner skin. The unarmoured ends being comparatively short in recent battle-ships, the importance of this kind of protection is not so great as it was in the central citadel ships of earlier date.

\section{Chapter II.}

\section{The Offensive Powers of Batrle-ships. Guns, including their Number, Size, Disposition, and Aminumitiox Supply. Tor- PEDOES. RANIS.}

Guns.-In the review we have just completed of the development of armour protection, we have seen how the battle-ships now under construction are the logical outcome not only of the many improvements in guns and armour, but of the endeavours made by constructors and naval officers to rectify the mistakes of the past and to approximate as far as possible to the most perfect fighting machine available with the means at their disposal. As with the armour so with the guns. When first the struggle between guns and armour commenced, the ships being practically completely covered with armour necessitated very large guns, and no advantage could be gained by mounting small guns in addition, but the increasing power of the gun limiting the area which could be defended, a great proportion of the ship's sides became open to common shell from comparatively light guns, and the weak spot being shown, guns were, of course, mounted to attack it.

Is the present position of affairs final ? It would be indecd rash to say: so. But under present conditions, whatever improvements we may make in matters of detail, there would seem to be no reason for altering the broad lines of the general policy upon which our ships are armed. This may, perhaps, be illustrated best by considering the effects which would be produced by withdrawing any of the types of guns with which our first-class battle-ships are now armed in future construction, and using the available weight to increase the offensive power in other directions.

At the present time our battle-ships are armed with four heavy guns, 13.5 or 12-inch, ten or twelve 6 -inch guns, and a large number of light quick-firing, 12, 6, or 3-pounders. Nachine guns do not enter into our consideration, as they can hardly have any appreciable effect in actions between fleets of battle-ships. Suppose the mounting of the heavy guns discontinued, and a larger number of medium guns provided, there would be at once a weak spot in our offence, of which rival nations would not be slow to avail themselves. They would build ships without any heavy armour, and would be able to defend themselves far more efficiently by protecting a much greater area of their ships with plates just capable of 
beating the 6 -inch gun under all conditions. Still less could we afford to dispense with the medium gun in order to increase the numbers or power of the heavy, for such a proceeding would greatly diminish our powers of attack on all thinly armoured or unprotected parts of the enemy, the form of attack which had such extremely important effects in the late wars. The object of the light Q.F. guns is principally to meet torpedo attacks, although they will be made use of against battle-ships as far as possible also. They cannot, on any account, be dispensed with. Indeed, it will hardly be disputed that all three types are absolutely essential to the efficiency of a modern battle-ship.

It is beyond the scope of this essay to go into all the details of improvements in modern naval artillery, but it will be necessary to take into consideration what are the principal qualities to be striven for to make the most efficient naval weapon attainable.

The first requisite for all naval guns is very high muzzle velocity with consequent low trajectory. The distinguishing characteristic of seafighting is the constant and rapid changes which will take place in the range. With the best range-finding in the world it will always be difficult to convey the information to isolated guns before the range has altered. The best gun for naval purposes is that which is least dependent on accurate information as to the distance of the enemy. All guns must have low trajectories, and guns designed to throw very large quantities of explosive by high angle fire, however suitable for attacking immovable forts of which the range can be accurately determined, are quite out of place in a fleet action. The second point to be considered is the power of the gun to attack armour. There are two ways in which armour can be attacked: Firstly, by concentrating the fire on one point and cracking the plate up by a number of heavy blows; secondly, by perforating the armour at each shot. The first method does not concern us, as if our guns are incapable of perforating the enemy's heavy armour it will always be better to direct them at the lighter armour and unarmoured parts, and to use common shell. Besides, such accuracy of fire as would be necessary to strike the same plate frequently would be quite unattainable in action.

The penetration of which a gun is capable can- be approximately calculated by formula based upon experiment, but for our purpose here it will be sufficient to say that the penetration depends chiefly on the energy of the projectile, which varies directly as the weight multiplied by the square of the velocity. But two projectiles may have the same energy and yet be of different calibre; in such a case the projectile of smaller calibre will have a greater penetrating power. In other words, the same penetration can be obtained with a small calibre with less energy than would be necessary in a larger calibre.

As regards the size and weight of the heavy guns most suitable to be mounted in battle-ships, 12 -inch guns have been provided in the "NIajestic" class and all later ships, and great improvements have been made in their design and construction, so that they compare very favourably with their heavier predecessors, as the following table will show. 


\begin{tabular}{|c|c|c|c|c|c|}
\hline Nature of Gun. & 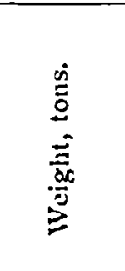 & 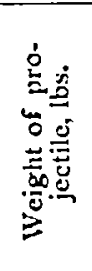 & 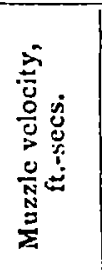 & 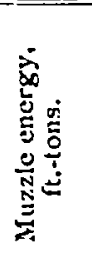 & 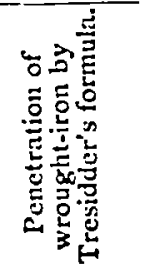 \\
\hline 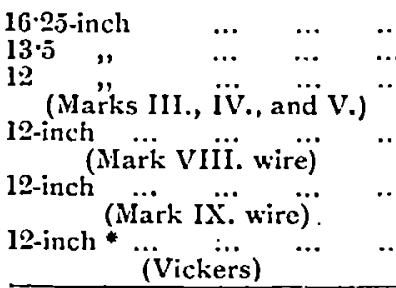 & $\begin{array}{c}110 \\
67 \\
45 \& 46 \\
46\end{array}$ & $\begin{array}{r}1,800 \\
1,250 \\
714\end{array}$ & $\begin{array}{l}2,087 \\
2,016 \\
1,914 \\
2,367 \\
2,600 ?\end{array}$ & $\begin{array}{c}54,390 \\
35,230 \\
18,130 \\
33,0 \geq 0 \\
?\end{array}$ & $\begin{array}{l}33 \text { inches } \\
33 \quad " \\
24.4 \quad " \\
36.8, \\
? \\
45.9\end{array}$ \\
\hline
\end{tabular}

"To be supplied to "Formidable."

$B y$ this table we see that the penetration which it is calculated will be obtained with the latest 12-inch gun exceeds that of the 110 gun of more than twice its weight. When it is considered that the smaller gun can be fired at least three times as fast, and that, having a higher velocity, it is less dependent on accurate range-finding, we get some idea of the rapid strides made in the construction of heary guns in the past decade. It is not to be supposed that the gun-makers are going to rest content with their achievements; but in vicw of what has been accomplished with the 12-inch, there at any rate scems no necessity to desire a lurger calibre. The length of the latest 12 -inch gun is 40 feet, and as. any increase in power will almost certainly entail a further increased proportion of length to calibre, it is more than likcly that future guns will be of less calibre and yet be equal, if not superior, in penetration to the 12-inch. The idleal gun for the attack of armoured ships is that which combines the qualities of low trajectory and great penetration- with comparatively light weight of gun and projectile.

With regard to the much argued question of the relative merits of barbettes and turrets, we have now settled down to a system which appears to combine the good points of both-the guns heing mounted in a barbette which effectually protects the loading and training arrangements, and the breechcs of the gun being defended by a thick inclined shield. Great improvements have been made in the arrangements for loading, which can be carried out in any position in recent ships, and the time necessary for the operation has been very greatly reduced; so that the rate of fire from heavy guns, which formerly was very slow, approaches the rate at which 6 -inch guns could be fired before the days of quick-firing. Arrangements arc now made so as to load and work all guns by hand in the event of machinery failing. These improved details have added enormously to the efficiency of the 12-inch guns now mounted, and have thus rendered them very superior to the $13 \cdot 5$-inch guns in the "Royal Sovereign" class. 
The heavy guns in our battle-ships are now invariably mounted in pairs in two barbettes on the central line, and this system is generally adopted in all new ships for foreign Powers. Other methods of mounting are the system of placing the turrets or barbettes en échelon, and single guns in three or four barbettes. In examining the merits of our present system as compared with these alternatives, we may appear to be at some disadiantage, on paper, in the weight of metal which can be thrown direstly ahead or astern, and also in the want of separation of the gunsa quality which would always seem desirable. With regard to the first point, it must be remembered that, while a great deal heavier fire is obtained by these methods in the line of the keel, this advantage is lost directly the bearing of the enemy changes by a very small angle, as the guns on the side cannot fire across the bow or stern. As to the question of separation, which does insure against the calamity of two guns being disabled by one shot, it must be remembered, on the other hand, that a less weight of armour is required to defend two guns side by side than two guns in separate positions. Other advantages which may be claimed for our present system are that, the guns being on the centre line, the magazine and loading arrangements are facilitated, and rolling and heel caused to a lesser degree than by guns mounted at the ship's side; and we might also add that with heavy guns mounted in pairs instead of singly; a smaller number of officers will suffice for efficient control. Last, but not least, the guns of the secondary armament will be interfered with much less when the main armament is on the centre line than when some of the guns are placed at the side. An inspection of plans of all recently constructed first-class battle-ships will show that, as regards the placing of the heavy guns, all nations are very much in accord with us, except France, in which country the heavy guns have generally been placed in separate positions, three or four in number-those on the centre line being usually placed nearer the ends than in our own ships. In the "Charlemagne" class we find some approximation to the British design, but the guns appear to be placed rather nearer to the ends of the ship than in "Najestic" and not to have such complete protection. Whatever may be said in favour of the dispersion of heavy guns, as in the "Carnot," it is plain that our "Majestics". will have the advantage in a sea-way, and that their guns are somewhat better protected.

I conclude that we have no reason to be dissatisfied with our battleships now under construction, so far as the heavy guns are concerned, though, of course, there will be further improvements in construction and detail.

I now come to the consideration of the secondary armament, which is now invariably, in the Briti h Navy, composed of 6-inch Q.F. guns, no heavier gun being mounted on the broadsidc. While no increase has been made in calibre, the powers of penetration have been very greatly increased ; for example, the 6-inch Q.F. guns of the earlier patterns could penetrate about 13 inches of wrought-iron, and the penetrations of the 0 -inch wire gun and Vickers 6 -inch of the latest pattern are 15:7 and $22 \cdot 7$ inches respectively. The power of Fronch guns has also been increased 
to a corresponding degree. While England and France have both fixed on a limit of about six inches for the calibre of the secondary battery, the United States have mounted 8-inch and 5 -inch guns. It will be well to compare the advantages of the two policies.

The purpose of the secondary battery is not to attack the heavy belt or barbette armour, but to explodle as many shells as possible in the enemy's batteries and other parts open to attack. The 6 -inch gun appears well suited in every way for this purpose, and by having all guns in the secondary battery of the same size, great advantages are obtained in the arrangements for the provision and supply of ammunition, as also in the triaining and organisation of officers and men. On the other hand, if we confine ourselves entirely to one size of gun for broadside mounting, the task of design as regards armour is much simplified for our possible enemies, who will regulate its thickness in accordance with the powers of the gun most generally in use by us. It has already been pointed out that the power of the 6 -inch gun has been very greatly increased in the later patterns, this incrcase being in great measure duc to the greater length of the new guns, and for broadsicle mountings excessive length, is extremely inconvenient and undesirable. The 50 -calibre 6 -inch Vickers gun has a length of about 26 feet, and can penetrate 22.7 inches at the muzzle. The 40-calibre 8-inch gun has a length of about 28 feet, and its muzzle penetration is 25.5 inches. When the increased weight of ammunition, slower rate of fire, and greater length of the 8 -inch gun are considered, the balance of advantage lies with the 6 -inch weapon. If the 8 -inch were increased to 50 calibres, in order to more perfectly develop its power, it would be about 35 feet long, which now seems an almost impossible length for a broadside gun, although there can be no certainty that in the future the guns of the secondary battery will not attain such dimensions. On the whole, it secms to me advisable to rest content with the 6-inch gun for the present, but, of course, developing its powers to the fullest extent possible, and replacing the older marks by their more powerful successors as occasion offers.

It is impossible to enter into a discussion of all the numerous improvements in mountings which have been made within the last few years, improvements which never secm to pause or cease, but it must be noted that their general tendency has undoubtedly been, firstly, by reducing the labour necessary at the gun itself, to cause a smaller crew to be required; and, secondly, by increasing the rate of fire, to make necessary larger ammunition supply parties and better facilities for getting the ammunition to the guns. The improved arrangements for the supply of ammunition which we see in the most recent battle-ships are by no means the least important of the many points in which the first-class battle-ship of the present is superior to the best ships of ten years ago. The idical arrangement for quick supply would be that each gun should have its shell-room and magazine directly below it, so that the ammunition could be hoisted straight from the magrazine to the gun. This, however, cannot be carried out, as the space directly below broadside guns must necessarily be largely devoted to the storage of coal. As 
now arranged, the ammunition is taken from the magazines and sheilrooms, which are placed before and abaft the engines and boilers, through passages on either side of the ship to separate hoists for each individual gun, so that each charge is handed up from the magazine, transported on one deck, and hoisted by a single hoist to the gun-a most marked contrast to the old conditions, under which there were generally two or three hoists, and as many transportations along different decks, before the charge reached its destination. Without some such well-devised arrangements as the foregoing, the full advantage of Q.F. guns cannot possibly be obtained. The great importance of very rapid fire is now most fully recognised, and very great improvements have been made in the mechanism of the gun and its mounting to attain the best possible results. So great, indeed, has been the advance in this direction, that the chief difficulty now is how to supply the ammunition quickly enough during the heat of action.

The number of 6 -inch guns mounted in a first-class British battle-ship is now twelve, and in this particular we seem to compare unfavourably with many foreign vessels. For instance, the Italian "Sardegna" carries eight $5 \cdot 9$-inch and sixteen $4 \cdot 7$-inch, or double the number carried by the "Majestic," although of somewhat inferior power. The Japanese "Shikishima" carries fourteen 6 -inch guns against the twelve 6 -inch of the "Formidable." In the case of the Italian ship the guns are not protected, and, of course, are placed very close together, and it is fairly certain that the twelve protected guns of the "Majestic" would be a match for them. No doubt the advantage which the Japanese ship holds of two additional 6-inch guns over the "Formidable" is paid for by a deficiency in some other quality, which is not so immediately apparent; but it is an advantage not to be lightly disregarded all the same, and there are many very good judges who think we have allowed ourselves to drop somewhat behind in this particular. Suppose it were intended to add two or more 6 -inch guns to future battle-ships without any large alterations in the general design of, say, the "Formidable" class, let us consider where they could be most advantageously placed. There is a large space unoccupied by guns before and abaft the bulkheads of the citadel where extra casemates might be'placed, two forward and two aft, or only two forward. . The arrangements for ammunition supply to these casemates would have to be considered, as they would be quite cut off from the ammunition passage which supplies the other guns. Small separate magazines directly below each gun not mounted in the citadel would be the best plan to adopt. There is also the space between the upper deck casemates now occupied by the 12-pounder battery. The Japanese have utilised this in the "Shikishima" and have put an extra casemate there on each sidc. The objection to this course is that the 12-pounders would have to be put in other and less suitable positions, or placed very much closer together. The question of the extra weight has, of course, to be considered-a weight which includes the guns, their mountings, and ammunition, and the armour necessary to protect them. Commander Robinson, writing in "Brassey's 
Naval Annual," 1898, p. 207, states the weight for the twelve "Magnificent's" cascmates to be 208 tons, or $17 \frac{1}{3}$ tons for each; say, 15 tons for gun and mounting and 12 for ammunition, about 45 tons for each extra gun would be required in actual weight. Allowing 50 tons for each extra 6 -inch gun mounted, this would be 200 tons for four additional-6-inch guns, which would be a small weight in comparison to the displacement of a 15,000-ton ship for such a large increase in power.

I an decidedly of the opinion that the number of guns mounted should be only limited by the space available for them, and the extra weight should be provided for by economies in other lirections, or in the last resort, by increased displacement. If we examine the development of the modern battle-ship as regards broadside guns, we find that while the "Dreadnought" and the "Thunderer" mounted none, the "Trafalgar" has six, the "Royal Sovereign" ten, the "Majestic" twelve, and the "Shikishima" fourteen. In the "Dreadnought" and "Trafalgar" there is no deck space available for more guns, but this is not so in the "Royal Sovereign" and later ships, which are all capable of carrying a more numerous broadside armament. I consider that the tendency at present is towards an increase of the broadside guns, and that the experience of a naval war would certainly create a demand for the greatest possible number that the deck space would admit of.

We now come to the consideration of the lighter Q.F. guns, viz., 12,6 , and 3 -pounders, and, as I have already stated, the primary object of these guns is for defence against torpedo-boat attacks. Some are mounted on the upper deck and in the tops, and others placed on the main deck at bow and stern, in the unarmoured parts of the ship. For example, the "Formidable" has cighteen 12-pounders, of which eight are on the broadside of the upper deck; four forward and four aft on the main deck, two short 12-pounders for boat work on the foremost breastwork, and twelve 3-pounders in the fighting tops. For the night work for which they are intencled it is certain that they are most effectively mounted in upper-deck positions, both for purposes of control and in order that the guns' crews may be in the most favourable position for discovering the attacking boats. As during a torpedo attack the boats will make no use of gun fire, which would only show their position, protection or shiclds for the guns are unnecessary, and by intercepting the view of the captains of the guns would probably militate against good shooting. A supply of ammunition would of course be kept at the guns at night.

During a fleet action these guns would be told off to fire at the unarmoured parts of the enemy's ships, and at the water-line if not defended by a belt. A supply of ammunition is usually kept ready at hand by these guns. It is worthy of remark that a box of 3-pounder ammunition in the "Baltimore" was struck and exploded at Manila, wounding two officers and eight men. (Sec Official Report, p. 78.) I would suggest that a ready rack to contain about thirty rounds and protected by 3 -inch plates should be placed between each pair of light Q.F. guns to guard against such mishaps.

With regard to the number of light Q.F. guns necessary for a firstclass battle-ship, I consider that it should be as large as possible, and only limited by the amount of suitable space available. 
To sum up, I consider that the system of mounting four heavy guns in two positions on the centre line should be maintained as at present, that as many 6-inch guns as possible should be mounted in casemates on the broadside, and that all the remaining available space on the main and upper decks and the fighting tops should be deroted to 12- and 3 -pounders, these being primarily intended to meet torpedo attack. However, no gun, 6-inch, 12- or 3-pounder, should ever be placed where its fire would interfere with that from other guns. I think a study of the development of our battle-ships since the introduction of armour teaches that this is the end towards which we are approaching, and that the beginning of the twentieth century will produce ironclads in which all available deck space will be utilised for gun-power, as was the condition existing at the battle of Trafalgar in the wooden line-of-battle ships of that date.

With regard to the different powers used for working heavy guns and providing ammunition, hydraulic power is at present the principal, but it is supplemented by electricity' and manual labour. 'To obtain a quick rate of fire with heavy guns it is absolutely necessary to provide more power than we can obtain by hand; but the wisdom of providing alternative means for carrying out all the operations of loading and pointing, at a slower rate by manual labour, is now fully recognised. The relative merits of hydraulic and electric power admit of much argument. Briefly stated, hydraulic power is alone suitable for absorbing recoil so far as present appliances go, and the available pressure is also more ensily regulated and kept constant. On the other hand, the transmission of power by electricity is effected more casily, and electric wires will be both less liable to damage and more ensily repaired than are hydraulic pipes. It must be remembered that the hydraulic system is older, and therefore holds the field ; electricity is only on its trial, and its possibilities are as yet by no means fully developed. With the great improvements now taking place in the manufacture of electro-motors for traction and other purposes on shore, it may reasonably be assumed that thoroughly reliable and efficient motors will be produced for ship work in the near future. When these are obtained, electricity will have great and undoubted advantages over both steam and hydraulic power for all auxiliary engines on board a battle-ship. 'Electro-motors were in' use in many of the United States ships during the late war, and in the Official Report we find mention made of them on two occasions, viz. (p. 74):- "Olympia ' reports failure of ammunition-hoist through the fuse blowing," or, as we should say, the safety cut-out fusing. Page 79 :-“" Baltimore' reports that 'ammunition supply was ample and the test was conclusive so long as electric hoists are uninjured.' "This testimony does not amount to much, but is very typical of the case as regards electric power on board ship, viz., electro-motors are very satisfactory so long as everything is in proper working order, but they are very liable to derangement by fallure of insulation, contacts being loosened by concussion, and other small causes. Their defects are such as can only be overcome by experience; but these defects being overcome, electricity is probably quite the best form of power for all auxiliary purposes, 
With reference to the means used for firing guns, electricity is now universally used for all guns except 6 -and 3 -pounders, pcrcussion firing being only resorted to on the failure of the electric circuits.

Electricity has the following advantages :-

1. Less muscular effort being required to press a firing-key than to pull the percussion firing lanyard, the gun is fired more instantancously, and shooting is improved accordingly.

2. The provision of "safety" gear, to prevent the guns being fired when in a dangerous condition, is simplified.

3. The electric primers being absolutely safe against ignition by concussion, can be kept in place in the cartridges when in the magazines.

These advantages have been considered so important, that electricity has bẹen universally adopted in our Service, and each gun is provided with two complete and independent batteries and circuits, percussion firing only being used when both of these have failed. Electric gun circuits, however, are liable to small defects, such as the loosening of screwconnections by the concussion of the gun, which would cause miss-fires in action. 'This liability' of electric circuits to failure was experienced by the Americans, and is frequently mentioned in the Official Reports on the late war. Mention is also made of using the dynamo circuit as an alternative to the firing battery; but apparently with indifferent success (p. 74, "Olympia" at Manila). Miss-fires with electric circuits are not infrequent at target practice with our own guns, but much has been done to remedy" defects in new circuits. The greatest drawback to electric firing is that, while everything may test perfectly and be in good order before firing, a few rounds may loosen a connection in a circuit and so cause miss-fires. Such a defect, though easily remedied when found, takes time to locate, and as it is extremely unclesirable to have such delays in action, many officers would prefer to depend on percussion firing only. The circuits now fittel are certainly less liable to failure than was the case a few years back, but I think there is still room for two improrements to make them more certain in action, viz. :-

1. Thie voltaic cells composing the firing battery should be larger and more strongly built.

2. All connections in the circuits should be made more secure, and more accessible than is the case at present.

A most important item of a ship's offensive powers, though one not generally taken into consideration in comparisons between our own and foreign ships, is the proportion. of ammunition to be carried on board. With the very rapid fire now attainable, it -is, of course, certain that a large supply is necessary; on the other hand, too much would be a waste of power, for the weight could always be profitably employed in other directions. It is, I think, a question of compromise, and most of us would prefer to err on the side of having too large a supplyt than too small. I do not think it desirable to go into the actual number of rounds allowed for guns in our own as compared with foreign ships; but having 
made some research into the matter, I am able to say that our guns are provided with a considerably larger allowance of ammunition than in any ioreign Nary, except the Japanese, which nation has adopted the British allowances for new ships. While on this subject, it will be remembered that Admiral Dewey withdrew temporarily from the attack of the Spanish flect, under apprehensions about his ammunition supply. He was without a base of supplies, and therefore the matter was of vital importance to him. There are some interesting details to be gathered from the Official Report in this connection, viz., p. 70, Admiral Dewcy states:- "At 7.35 , it having been erroneously stated to me that only fifteen rounds per gun remained for the 5 -inch rapid-firing battery, I ceased firing and withdrew the squadron for consultation, and a re-distribution of ammunition, if necessary." At p. 74:- “The captain of the 'Olympia' states the whole expenditure of 5 -inch shell as 281 for the ten guns" ; so that Admiral Dewey was in doubt about his supply, when only twenty-eight rounds a gun had been expended! I leave the figures to speak for theinselves to those who know what the allowance is for Q.F. guns in the British Navy.

Continuing the consideration of offensive powers, I now come to the torpedo. The Whitehead torpedo was first introduced in the Navy in 1878 , and at that time was a slow and very unreliable machine. From that date vast sums of money and the brains of many clever men have been devoted to its improvement, with the result that torpedoes now inanufactured run very accurately for a distance of 800 yards at a speed of 30 knots; and if the torpedo be correctly adjusted and fired at the right moment, the chances are much in favour of its striking the enemy up to a range of 600 or even 800 yards. Considering all these improvements, it might reasonably be expected that torpedoes would have played a most important part in the two wars under consideration; yet there is not a single instance of the successful use of a torpedo by one ship against another. I think that the reason for this is to be sought, not in the imperfections or failure of the torpedo, but in the simple fact that the torpedo is not the weapon of the battle-ship. With the breech-loading gun of to-day accurate practice can be made at very long range, and it secms probable that most naval actions will be virtually decided quite outside the reach of any torpedo yet designed. The battles of Minila and Santiagro are confirmatory of that opinion. The former action was fought and decided at a distance varying from 5,600 to 2,000 yards (Official Report of Captain Gridley, "Olympia," p. 73); and at Santiago, when Admiral Cervera left the harbour, Captain Evans, of the "Iowa," gives the range at which he opened fire at 5,000 yards, which was diminished to 1,600 shortly before the "Teresa" and "Oquendo" ran ashore. Captain Cook, of the "Brooklyn," also states that he was firing at the "Colon" at a distance of 6,800 yards, the "Oregon" firing at a range of 8,900 yards at the same time, when the Spaniard turned for the beach. ("The Story of the Captains," Century' Magazine, May, 1899.)

Nerertheless, I am not at all of the opinion that torpedoes should be dispensed with in British battle-ships. Such a step would place 'us at a 
great disadvantage, as it would give our opponents the option of forcing a close action at torpedo range, the avoidance of which would greatly fetter the tactics of our own flect.

Torpedoes were exploded in the above-water-tubes in the "Vizcaya" and "Oquendo" at Santiago; whether the cxplosions were the direct result of shell-fire, or, as is more probable, were caused by the fires started by the shells, it is plain that the use of above-water tubes in battle-ships can no longer be defended, and that such should all be removed from ships in which they now are. The submerged tubes should be retained, and the four provided in the latest types of first-class battle-ships are amply sufficient. Submerged tubes being on a fixed bearing, it is necessary to consider what is probably the most advantageous training to give them, and on this point there is little or nothing to guide us. If two ships pass each other on opposite parallel courses, the beam position will give the shortest range and the best target at which to fire, but I venture to think that this will be an unusual and quite exceptional casc. My own opinion is rather that the opportunities for the successful use of a torpedo will more generally occur when one ship is ajproaching another for the purpose of cutting off her escape, or in the attempit to ram. In such a case the courses of the two ships will gencrally be oblique to each other, and a torpedo-tube laid on the bow or quarter will probably have a better chance of a shot than one on the beam. I should prefer to have the four tubes placed two on the bow and two on the quarter. Believing, as I do, that the use of torpedoes by battle-ships will be exceptional, and because a torpedo-tube cannot be very rapidly reloaded, I do not consider a large supply of torpedoes necessary. 'Two torpedoes to each tube, or eight for a ship is, I think, a sufficient number.

The ram has had no appreciable effect in the fleet actions we have to consider in this essay. There was no instance of even an attempt to ram by Americans or Spaniards either at Manila or Sintiago. In the battle of the Yalu; the Japanese ships made no attempt to ram, but trusted entirely to their superior gun-fire. The Chinese assert that their ship, the, "Chih Yuen" successfully rammed a Japanese ship, afterwards sinking herself. As it is certain that no Japanese ship was sunk, if there be any truth in the Chinese version at all, it is possible that the "Chith Yuen" rammed her consort the "ling Y'uen" which was next her in the line and also sunk.

Vessels specially built for ramming, with high speed and very good turning powers, have been frequently adrocated, and in the "Polyphemus" and "Katahdin" we have two vessels in which this principle has been worked out. 'The greatly increased power and accuracy of naval artillery" has, however, robbed these ships of much of their terror, and no more vesscls built primarily for ramming are now under construction.

The ram, like the torpedo, is a weapon of secondary importance as compared with the gun, but like the torpedo, it must necessarily be retained, because the want of it would put our flects at a tactical disadvantage. The ram, then, being a necessity to the modern war-ship, we are only concerned with the quesiion how to make it ats efficient as possible, without impairing the gun-power or o:her qualities of the ship. There are two 
separate questions which make for the efficiency of a battle-ship to ram an opponent successfully.

Firstly, a ship must have good speed and manœuvring power in order to strike a blow at all.

Secondly; she must be constructed on a principle which will adnit of her infleting severe damage to the cnemy with the least possible hurt to herself.

As regards the first qualification, good speed is a necessity for other considerations more important than ramming, and is well provided for in all recent construction. Twin screws are also a necessity for other purposes besides successful ramming tactics. 'l'urning-power under helm, which is essential to ramming tacties, has been improved in the "Formidable" as compared with " Majestic" by cutting away the deaclwood before the stern post to a height of 11 feet. This device was first introduced in battle-ship construction by Mr. Philip Watts, of the Elswick liorks, in the Japanese "Yashima." There arc many other details which add to or detract from a ship's turning powers, which space does not admit of $m y$ discussing; but I think I may safely state that the 15,000-ton battle-ships of to-clay compare very favourably with their smaller predecessors in this resr et, and that the charge of unwicldiness sometimes brought against them is unfounded.

As regards the second qualification, the unfortunate collisions which have occurred between battle-ships in peace-time have sufficiently demonstrated the power of the ram to inflict crushing injuries on an opponent; but this has always been at the expense of considerable damage to the bows of the ramming ship. In the case of the "Camperdown," great injury was caused to her by the armoured deck of the "Victoria" cutting into the plating just below the water-line. It is to be remarked that the damage to the "Camperdown", did not occur at the ram itself, which is well supported to resist strain, but at the weak plating on the bows above. The ram of the "Camperdown" being very sharp and pointed, easily penetrated, and absorbed only a very small part of the shock of collision. The ram in the "Royal Sovereign" and later ships has not so much the nature of a sharp spur, and is constructed on a bluffer model, which consequently would not enter a ship's side so easily, but would absorb a greater proportion of the whole blow, so leaving a smaller blow to be received by the comparatively weak bow plating. It is probable that the "Royal Sovereign" would suffer much less in ramming than did the "Camperdown." The "Formidable" is still further improved in this direction by a 2 -inch nichel steel plates on the bows in addition to the ordinary skin plating of 4 -inch; the ram itself is greatly stiffened and strengthened as compared with former models, and to preserve the collision bulkheads intact, the horizontal stiffening plate which is placed inside the ram is carried aft to the seventh frame only, so that the blow will not be transmitted by it to the collision bulkhead at the eighth frame, and any injury suffered in ramming will be confined to the collision compartment. The space from the ram to the serenth frame is also packed with cork contained by subsidiary bulkheads, so that small injuries to bow-plating need not necessarily fill the collision compartment: 
To sum up the requirements for offensive power in British battleships :-

So long as the British Nary is to hold its present position of superiority, it may be admitted that our persomel should be at least as well trained as any of our rivals. This premise being granted, it follows that, to, reap the full benefit of our superior strength, we should rely principally on that weapon which demands the highest degree of training of a ship's company. This weapon is, without doubt, the gun, and therefore gun-power should be developed in our ships to the fullest extent possible, by: mounting as many of the best guns of the most suitable types that the ship can carry, and supplying them with a fully adequate amount of ammunition. To guard ourselves against being rushed into close action where superior gunnery would not tell to ats fullest advantage, it is necessary to furnish our ships with torpedoes and $\mathrm{m}$ s on the lines I have indicated.

\section{Chap'Ter III.}

The Speen, Exgines, Bollers, Auxiliaky Michinert, and CoAi. SUPILY OF BatTI.E-SHIPS.

In discussing the question of speed in modern battlc-ships it is necessary to bear in mind that, as a general rule, they will be required to act in company in a flect, and that independent duties will be exceptional in war. A flect composed of ships of about equal steaming and sea-keeping powers has immense adiantages as against a mixed assembly of ressels fast and slow, large and small. Very much has been said and written of late years as to the importance of speed in naval warfare, and all peace manoures seem to confirm the theory that high speed is all-important. It must be remembered, howerer, that in manouvres the speed is practically the only factor in the game which is not artificial, and we should beware accordingly of 'attaching too much importance to it. Eyen in a squadron of battle-ships of the latest design and construction it is not to be expected that all will be able to attain their trial speed at the same time. It is often stated that the speed of a feet is that of the slowest ship. It is not less true that in a squadron composed of ships having equal trial speeds, the speed of the flect will be considerably less than that of which the individual ships are capable. I do not think that it would be under-estimating the speed of a flect of battle-ships to put it at two knots less than the trial speed of the individuals. The speed of a squadron thus limited, it is clear that with a flect in company very high speed of individuals is to a certain extent waste of power.

In every ship there is it certain critical speed beyond which any increase can only be obtained bj relatively very large increase in power and coal consumption. Without under-rating the great importance of high speed in modern war, I consider that in the full trial-speed of battle-ships we should not endeavour to greatly exceed that which can be 
obthined without excessize expenditure of power and weight. In short, we should be content with a little more than the critical speed above mentioned.

There is no question that the efficiency of a flect would be greatly increased by high speed, if it could be obtained without detriment to other qualities, but that is not possible, and as it is a case of a compromise I think we should be content with a sea-speed of about 16 knots for firstclass battle-ships as a general rule. Battle-ships, specially designed for service as flag-ships on distant stations, are exceptions to this rule, as they will not usually act in a feet, and high speed will be of greater importance to them because a very large proportion of the naval forces on the station will probably consist of fast cruisers. Fxamples of such battle-ships builc in recent years are the "Barfleur," "Renown," and "Canopus," in which high speed has been obtained by providing thinner armour and lighter gun-power. In fact, these ships are all a compromise between battle-ships and cruisers.

The following table gives particulars of the tonnage, H.P. full measured mile speed, and coal capacity of some typical battle-ships of the last ten years :-

Parliculars of Steaming Powers of some typical Batlle-ships.

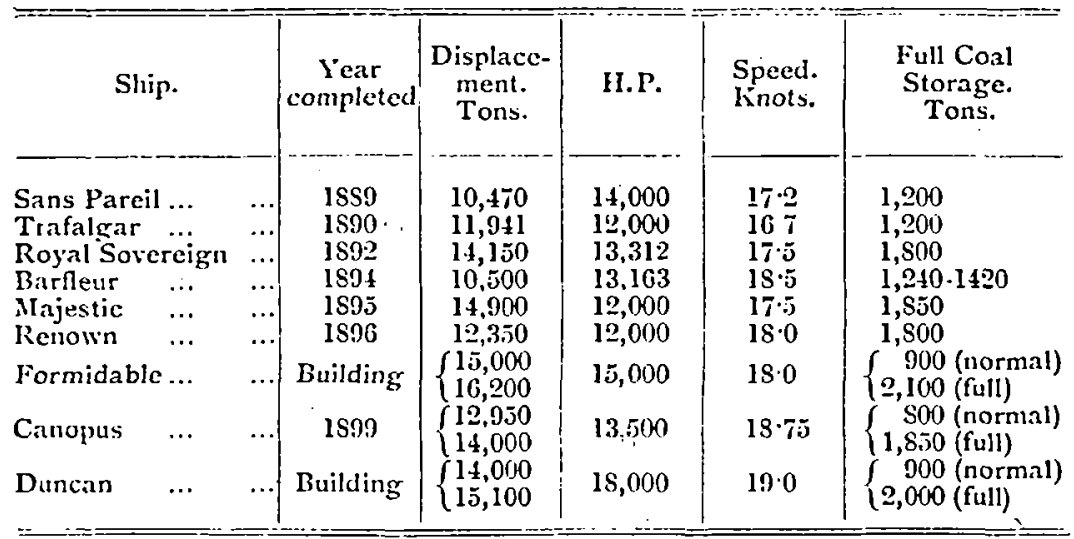

It will be noticed that higher speed in the later ships is obtained with a less proportionate H.P. This is due to greater length and consequent finer lines. Full speed under the usual conditions will generally fall short of the trial speed, but the difference is certainly much greater in the carlier ships than in the later ones. "The increase of speed in the "Formidable," now building, is, we sce, only half-a-knot over that of the "Royal Sovcreign," completed in 1892, and the "Canopus" has an advantage of only a quarter of a knot over the "Barfeur." For a period of about seven years the increase is not a considerable one, as it is only in the nature of things that there should be some improvement. In the latest design of battle-ship (the "Duncan" class), however, the full trialspeed has been advanced to 19 knots; these ships are somewhat smaller and less heavily armoured than the "Formidable," but have 3,000-H.P. 
more. Whether this change is a wise one is certainly open to argument. While, on the one hand, amongst a fleet of battle-ships of carlier date the high speed of the "Duncan" might be considered a waste of power, it must be remembered that we have by no means reached finality as regards speed, and the high speed of the "Duncan" may possibly in the future, twelve or fiftecn years hence, enable her to take a place in the feet of that day without danger of being a drag upon her newer consorts, as she might be if originally designed for a lower speed. On the whole, I am inclined to the opinion that a somewhat exaggerated value has been assigned to the quality of speed in the "Duncan" battle-ships, and that some of the extra weight allowed for machinery would have been more profitably employed in increasing the area protected by armour, or in an increase of gun power.

In considering the effective full-speed of battle-ships, it must always be borne in mind that a flect of battle-ships will in war-time, rarely if ever, be required to steam for long distances at full power; on the other hand, they will generally be required, while cruising at comparatively slow speed, to have steam and engines ready to proceed at full power at the shortest possible notice. The battle of Santiago is a case in point. The Spanish cruiser "Colon" issuing suddenly from harbour, was able at first to run right away from the American ships, leaving them five or six miles in the rear, although when they had raised full steam at least three of them were able to catch her. The American cruisers, "Brooklyn" and "New" York," were put at a great disadvantage by the design of their engines (viz., two separate engines to each screw, like the "Blake" and "Blenheim), for the duties of blockade at slow speed; only the afterengines were coupled up, and the delay which would have been caused by stopping to connect the forward engines was so great, that they were obliged to chase with the after engines only. The lesson, of course, is that battle-ships should always have full power ready at the shortest possible notice, and that anything in the design of either engines or boilers which militates against this important requirement, whatever be the gain on a measured mile trial, cannot for one moment be admitted. The principal advantage of the water-tube boilers lies in this requirement, as steam can be raised in them so much more rapidly than with the old type.

That water-tube toilers have been so generally adopted is probably, however, due less to their undoubted tactical advantages, than to the fact that a given power can be obtained with less weight and space than are necessary for cylindrical boilers, and this because pressures can be attained in the former which are quite impossible in the latter. On the other hand, the construction of tubular boilers necessitates a very large number of joints, all of which are possible sources of leakige and loss of water. With the possible leakage to face, it is necessary to carry an extra quantity of fresh water, so that much of the economy of weight in the boilers is lost by the extra weight of water which it is necessary to carry. Water-tube boilers are generally considered to be very extravagant of coal, and there is certainly some ground for this charge; for although 
very good results are obtained as regards economy at full speed, at lower speeds which should be much more economical, the coal burnt per I.H.P. is not found to have decreased so much as we might expect. The reasons for this were well explained in " Brassey's Annual," 1809 (Chap. 10), and may be stated briefly to be as follows :--

Firstly: The engines are designed chiefly for full speed, and do not therefore work economically at lower spceds.

Secondly: There is a great waste of power in the auxiliary engines, which waste is caused by the loss of heat and condensation of steam in the long auxiliary steam-pipes. This loss must necessarily be greater, the higher the pressure of steam in the boiler, and therefore bears a larger proportion to the total power with water-tube boilers, than with cylindrical patterns, which work at lower pressures; the expenditure for the auxiliary service also bears a greater proportion to the whole at low speeds, hence the extravagant consumption per I.H.P. at low specds.

In regard to water-tube boilers and the defects to which they are liable, it is only fair to remember that this is a new development in marine engincering; that results can be achicved with these boilers impossible with the cylindrical type, and also that when cylindrical boilers with comparatively high pressures were introduced in battle-ships of the "Admiral" and other classes, the same difficulties of leaky tubes, etc., were encountered that we now hear so much about in connection with the watertube type. A very noticeable objection to the water-tube boilers hitherto supplied is the dense volumes of smoke made by them. In regard to this 'defect also, we should look back to the past and remember that in the early days of cylindrical boilers, ships were not so blameless in this respect as is the case at present. The remedy with water-tube boilers will be found in time, and, by experience, probably in some re-arrangement of funnels and combustion chambers; it is possible also that, with more perfect combustion in the furnaces, more economical results will be obtained in the coal bills.

I believe the tactical advantages of water-tube boilcrs to be so great that they have certainly come to stay, and that their deficiencies will be overcome by experience, as were those of the cylindrical boilers a few years ago.

Any review of the requirements of steam power for battle-ships cannot be complete without some reference to the question of auxiliary machinery. The modern battle-ship is dependent on machinery for a multiplicity of different objects, viz.:-lighting, ventilation, boat hoisting, cable work, working guns, air compressors, and fire pumps, to mention some of the most important. This machinery, at present driven by steam, absorbs no small part of the total boiler power, and is responsible for much of the coal consumption. The auxiliary engines being in all parts of the ship, necessitate a vast amount of steam piping, which heats the ship below very much, and is extremely wasteful of coal by reason of the condensation of steam in the pipes. It is also a matter of common knowledge that the defects in machinery (to which modern ships are unfortunately too prone) are of far more frequent occurrence in the auxiliary engines than in the 
propelling machinery. No doubt a reason is to be found for this in the fact that the auxiliary machines, distributed in many parts of the ship as they are, obtain less skilled attention than do the large main engines; but an engine connected with the boilers by a very long steam pipe, and only working intermittently, is liable to receive steam containing a certain proportion of water, and this is, I believe, one of the most fruitful catuses of defects in steam machinery. The large amount of steam piping necessary for our auxiliary machinery I regard as an unmixed evil, and with the great development now going on in electrical machinery on shore, I think it is possible that the remedy is at hand. Electricity has been very rightly regarded with suspicion hitherto; trials of motors on board ship for various purposes have certainly not been attended with conspicuous success, and it has never yet been applied in a war-ship on a large scale for the many purposes $I$ have indicated. The obstacles are many, but I believe them to be not insurmountable, and that if one of the great electrical engineering firms were given a free hand, as an experiment, they would provide a ship with efficient electrical auxiliary machinery for all purposes. But such an experiment must not be done by halves, as no advantage could then be gained. All anxiliary engines situated outside the engine-room and stokehold should be driven by electricity generated at a large dynamo station placed conveniently for obtaining steam.

The advantages to be claimed are:-

1. Less waste of power and coal, there being no condensation of steam when engines are at rest.

2. The motors', if the installation is well designed and efficient, should be less liable to defects and break-downs than are small steam engines which can be but imperfectly superintended.

Of course, it is not to be expected that so great a change could take place without much failure and disappointment, and it is possible that the time is not quite ripe for such a change as yet, though $I$ think it is not far off being so.

In the matter of coal supply, our battle-ships are, on the whole, considerably better provided for than are those of foreign Powers, and this fact accounts in no small degree for their greater displacement. The strategy of any future war in which Great Britain may be called upon to engage, will probably give the choice of the time of action to our opponents rather than to ourselves, for the reason that we, having and desiring to keep command of the sea, shall have to maintain our ships in readiness for the enemy's attack until such time as he chooses to challenge our supremacy. This being so, it is sufficiently obvious that it is absolutely necessary our battle-ships should have a larger coal supply than those of our rivals. Intimately connected with the question of coal supply is that of coal economy, which is very greatly dependent on the general design of the engines. For instance, a 20 -knot ship may be designed with engines intended to work as economically as possible at full speed; such a ship would be wasteful of coal at low and moderate speeds, but would be comparatively economical when running continuously at full 
speed. A similar ship might also be designed having engines equally capable of driving her at 20 knots, though not working economically, and would burn more coal at high speed though less at a moderate specd than the former vessel. As it is not to be expected that battle-ships will usually steam long distances at full speed, it is certainly more desirable that the engines should be designed with a riew to economy at moderate, say three-quarter, speed, rather than for economy at full power.

That the auxiliary machinery is very extravagant. of coal I have already pointed out, and also the remedy which $I$ think offers the best prospect of mitigating the eril.

\section{ChAPTER IV.}

\section{Sha-golig Qualities. Free-hoard and Stability. Prevention ANo Extinction of Fires in Action. Various Details in THE EQuipueNt of BatTle-ships.}

High frec-board is absolutely necessary to a battle-ship if she is to obtain a high rate of speed against a head sea. It gives the guns a better command, and by increasing the reserve of buoyancy, the inmediate danger of sinking by torpedo or ram is much diminished. On the other hand, the target offered to the enemy is necessarily much larger than in a low free-board ship. The change from low to high free-board was only made, in the British Navy, after the former had been tried at sea and found wanting.

The stability and steadiness of a ship as a gun platform depend on a great varicty of causes, into which it is unnecessary to enter in this essay. Since the improvement of the "Royal Sovereign" class by the addition of bilge kecls there has been no reason to complain of these or subsequent battle-ships for want of steadiness.

The absolute necessity of making ships sea-going in all respects was well shown during the Spanish-American war, when the American coast-defence monitors so hampered Admiral Sampson's movements on Porto Rico, they having to be taken in tow owing to their frequent breakdowns. (See Official Report, p. 368.)

Perhaps the most important of all lessons to be learnt in war-ship construction from the Chino-Japanese and Spanish-American wars is the great incendiary effect of the modern shell. Fires were caused by shell explosions in the ships of all four nations, but while the Japanese and Americans succeeded in overcoming the names, the Chinese were not so successful, and the Spaniards seem to have been in even worse case than the Chinese, the defeats of Manila and Santiago being directly brought about by the incendiary effects of shell explosion.

The lesson to be learnt is two-fold.

Firstly: Our war-ships should be made, as far as it is humanly possible, fire-proof.

Secondly: The provision for extinction of fire in action should be as complete, and as little liable to derangement as possible: 
With regard to making ships fire-proof, the Chinese and Spanislı ships were undoubtedly in much worse case than ships as now built for our Navy, because their wooden decks, being laid directly on the beams, could be ignited from below. All wooden decks in our ships are now laid over an iron deck, which, of course, makes an immense clifference, it bing almost impossible to start a fire on a deck so buill." However, many of our older ships are in no better condition than w.re the Spaniards in this respect, and would probably suffer as severely, could the flames not be subdued. As such ships coms to the dockyards for extensive refit, it would seem to be wise to consider the question of providing them. with steel decks where necessary and feasible. The custom of caulking decks with oakum renders them unnecessarily inflammable, and it would not be impracticable to make the seams water-tight by other means, such as coment or putty. Much is now being done in all Navies to dispense, as far as possible, with the use of wood in war-ship construction. In the latest German ships wood is almost entirely abolished, the Japanese also. in their new ships have almost entirely dispensed with it "xcept for the upper deck. In the description of the "Kasargi" (R.U.S.I. Jouknar, Nay; 1899 , p. 562), we read that wood has been almo-t entirily done away with, even the men's lockers on which they sit at th ir messes being steel boxes, and the captain's cabin ceile 1 with steel. New Am rican ships have been fitted with non-inllammable wood, and this material will be used in future British ships for all wood-work except decks. British ships now under construction cannot be said to be entirely satisfactory' in this respect; there is still a great deal of wood-work between decks, especially in the officers' quarters and on the mess decks, and our constructors have certainly not gone so far as the Japanese in reducing it. One purpose for which wood is now used seems particularly unnecessary. I refer to the ornamental moulds covering the junction of deck and beams. These would probably be stripped off by most officers in war, if sufficient time was available after more important matters had been attended to. Officers' cabin furniture is naturally of an inflammable nature, and if the cabins are kept in the usual peace condition, would form an undoubted danger. Stowage for much of this might certainly be found below the armoured deck in war, so that the cabins would be as empty as possible. This would, of course, cause some disconfort, but that should not be allowed to interfere with fighting efficiency for one moment. WVe must remember that in Nelson's ships, the bulkheads were often taken down for many months at a time. Though our new ships are undoubtedly. much less liable to fire than those of ten years algo, I consider that much yet remains to be done in the way of abolishing inflammable fittings. Noninflammable wood may solve the difficulty, but I would also suggest that use might be made of asbestos, silicate of cotton, or other fire-proof fabric for screens, etc. Hammocks should be made of non-inflammable fabric, and the decks should certainly no longer be caulked with pitch. Change in details such as I have suggested is necessarily slow; but the

1 See Admiral Wilson's remarks on Admiral Colomb's lecture, R.U.S.I. Jolirial, Vol. XLIII., page 449.

VOL. XLIV. 
cardinal importance of preventing fires in action must not be lost sight of, if the highest degree of fighting efficiency is to be obtained. When the older ships cone to the dockyards for extensive refits, they should be stripped of all wooden bulkheads, etc., which should be replaced as far as possible by steel.

It is unfortunate that we have no atccounts of the preparations made by Admiral Cervera's ships at Santiago for the prevention of fire. In view of the experience of the Yalu, and knowing the exact time at which the action was to take place, the decks of the Spanish ships should have been an inch deep in water and everything, inflammable thoroughly saturated with water before leaving harbour. Was this done? The answer is, probably, No. With the best preparation in the world it is still probable that fires will occur. I now propose considering the means which should be provided for their extinction.

So long as steam is the power utilised for auxiliary purposes, the present system of a fire-main throughout the ship is probably the best. The main pipes should be below the armoured deck, and vertical pipes taken up from them in each compartment; this is approximately the system now in use, but greater care should be taken to make use of any protection available for the rertical pipes, which are now often much exposed. Valves should be fitted to each branch of the fire main in accessible positions, so that a damaged pipe may be readily shut off. (Admiral Cervera in his report states that among the first injuries sustained by the "Maria Teresa" was the bursting of an auxiliary steam-pipe and the water mains.-Official Report, p. 560.) Should electricity be adopted for power for auxiliary purposes, one of the most important improvements that could be effected would be to replace the fire main system by small pumps in each compartment, which could be turned on the moment they were required. In addition to pumping facilities, a good supply of water should, of course, be at hand in tubs, with fire buckets by them. Everything inflammable should be thoroughly saturated with water on going into action. By these means fires can be best subdued before they have attained great proportions.

In fitting out a battle-ship for sea many things are necessarily provided which can have no direct effect on her fighting efficiency, but which, nevertheless, cannot be dispensed with, if she is to be prepared against all eventualities. The limits of this essay do not admit of a full discussion of the value of all these accessories, a list of which would contain such articles as submarine mines, electric cables, torpedo nets, spare propeller blades and crank shaft;, Temperley transporters, etc.; many of these might be kept in a separate fleet store-ship, or retained in the dockyards. The proper value of the stores I have named, and many other equipments of a modern battle-ship, is largely a matter of opinion; but to generalise, it will be allowed that all of these things have a certain weight, small though it be, and that if any of them could be dispensed with, the ship's fighting powers, whether'offensive, defensive, or motive, might be increased in a corresponding degree. I do not think my contention will be contradicted by those acquainted with both British and foreign ships 
that our ships are certainly more liberally provided with stores and fittings, which are not vitally important for fighting purposes, than those of our rivals. This is as it should be, if our Navy is to maintain a supremacy under all conditions and to be fairly independent of dockyards and store-ships, but it necessiarily entails a larger displacement for a gizen poicer. I think that those who have seen a battle-ship's stores returned to the dockyard on paying off, and have noted the multitudinous articles which have never been used since the day of commissioning, will agree with me that there is room for a pruning process, which would save valuable weight for application to more important purposes.

\section{PART II.-CRUISERS.}

\section{Chapter I.}

Distinction betweri Cruisers axp Batrlf-Ships. Dutifs of Cruisers. Remakes on the Developaent of Cruisers in the Britist Nave durisg the tast Tweaty Years.

With regard to the terms "battle-ship" and "cruiser," it may in some cases be difficult to decide how a particular ship should be classified; but, while it is not to be supposed that a cruiser will never be in a position to engage a battle-ship, the duties and purposes of the two classes are absolutely distinct. 'The battle-ships and cruisers of to-day appear to be on a preciscly parallel footing to the line-of-battle ship and frigate of the past, and it does not appear probable that the cruisers of the present will, under ordinary circumstances, take sta ion in a fíect of battle-ships, any more than did the frigate of old take a place in the line of battle. Battle-ships are necessary, and absolutely ne sssary, to obtain command of the sea in a war between first-class naval l'owers, but they must be supplemented by cruisers for the purposes of scouting. and commerce protection--duties for which the battle-ship is unfitted by reason of lack of speed and large coal consumption.

The principal duties of cruisers in war-time are threefold, viz. :-

1. Scouting to reconnoitre the disposition and movements of the. enemy:

2. Protection of commerce.

3. Attack of commerce.

The third duty will, with us, be entirely subordinate to the other two, and should have no influence on the design of any ship for the British Navy. 'Twenty years ago, cruisers, as we now understand the term, were practically non-existent. There were, indecd, large numbers of unarmoured masted corvettes and some frigates in the British Navy; but with few exceptions-such as the "Inconstant" and "Active"these were inferior in speed to such battle-ships as the "Alexandra" and "Dreadnought" (the speed of the "Gem" and "C" class corvettes was only about 13 knots). The first essential for all cruisers is that they 
must be superior in speed to the battle-ships, just as sailing frigates were faster than two-deckers. Unless the cruiser hats the legs of the enemy's battle-ships she cannot possibly carry out her duties efficiently.

'The cruisers of to-day may be said to have been developed from the "Leander" class, launched in 1882, and the following table contains some particulars of the principal types of first and second-class cruisers" from the "Leander" to the "Drake" :-

\begin{tabular}{|c|c|c|c|c|c|c|c|}
\hline Ship. & $\begin{array}{l}\text { Year of } \\
\text { Launch. }\end{array}$ & $\begin{array}{l}\text { Displace- } \\
\text { ment. }\end{array}$ & H.P. & Speed. & $\begin{array}{l}\text { Vertical } \\
\text { Armour. }\end{array}$ & \multicolumn{2}{|c|}{$\begin{array}{l}\text { Armoured } \\
\text { Deck. }\end{array}$} \\
\hline $\begin{array}{l}\text { Leander } \\
\text { Mersey }\end{array}$ & $\begin{array}{l}1852 \\
185 \%\end{array}$ & $\begin{array}{l}4,300 \\
4,050\end{array}$ & $\begin{array}{l}5,000 \\
6,000\end{array}$ & $\begin{array}{l}16 \cdot 6 \\
17 \cdot 3\end{array}$ & $\begin{array}{l}\text { Nil } \\
\text { Nil }\end{array}$ & ${ }_{3=2}^{1}$ in & nch \\
\hline Undaunted & $1 s s 0$ & 5,600 & 8,500 & $18 \cdot 1$ & $\left\{\begin{array}{l}10 \text {-in. side } \\
16-\text {-n. bulkh'd } \\
10 \text {-in. side }\end{array}\right.$ & $3-2$ & ' \\
\hline Warspite & 1858 & 8,400 & 10,000 & $16 \cdot \tau$ & $\left\{\begin{array}{l}\text { 9-in.bulkh'd } \\
\text { 8-in. gun } \\
\text { positions }\end{array}\right.$ & $3-2$ & $"$ \\
\hline Hawke & 1891 & 7,350 & 12,000 & $20-0$ & G-in.casemates & $5 \cdot 1$ & ", \\
\hline & $15 !$ & & 0,000 & $20 \cdot 0$ & Nil & & $"$ \\
\hline Astraea & 1893 & 4,360 & 9,112 & $10 \cdot 75$ & Nil & 2.1 & ", \\
\hline Eclip: & $18 !$ & 5,6 & 9,600 & 200 & $\mathrm{Nil}$ & $3 \cdot 1 \frac{1}{2}$ & " \\
\hline & 180 & 14,200 & 25,0 & $2 \cdot 2 \cdot 4$ & 6-in casemates & $c-3^{2}$ & ," \\
\hline Diadem & 1890 & 11,000 & 16,500 & 205 & $\begin{array}{l}4 \frac{1}{2} \text {-in. } \\
6 \text {-in. K.S. }\end{array}$ & $6-3$ & $"$ \\
\hline Cressy & Building & 12,000 & 21,000 & $21 \cdot 0$ & $\left\{\begin{array}{l}\text { belt and gun } \\
\text { positions. }\end{array}\right.$ & $3-2$ & ", \\
\hline Drake... & Building & 14.100 & 30,000 & $23 \cdot 0$ & $\left\{\begin{array}{l}\text { 6-in. K.S., } \\
\text { belt and gun } \\
\text { positions. }\end{array}\right.$ & $3-2$ & ", \\
\hline
\end{tabular}

Consideration of the plans of these ressels will show that from the "Leander" to the " Eclipse," all have been designed with a view to high specd combined with moderate protection to machinery and flotation, the guns being unprotected except by shiclds in all but two instances, viz., the $9 \cdot 2$-inch guns of the "Warspite" and the 6-inch casemate guns of the "Hawke" class. The "Undaunted" and "Varspite" classes are generally,termed armoured cruisers, by reason of the belt armour over their machinery, in contradistinction to the deck protection in the "Hawte," but this does not affect the principle on which they have been constructed, viz., sood defence of machinery and flotation, and poor defence of guns.

'The majority of ships engaged in the two late wars, we have to consider, were cruisers, and the general lesson to be learnt is, I think, that the battles were lost, not by damage to the machinery or water-line, but by the effects of shell explosions amongst the guns' crews and the upper parts of the ship. A ship like the "Dupuy de Lôme," or the "Colon," in good hands, would have been far more effective in these wars than the deck-protected cruisers which formed the majority of the forces in all the flects. We see the effects of this experience in the "Powerful" and the "Diadem," which were designed just after the Chino-Japanese war, their 
guns being much more efficiently protected than were those of any previous cruiser. In the "Cressy," "Drake," and new 9,800-ton cruisers much greater importance is attached to the defeat of shell attack by vertical armour than in any previous cruiscers in our Nay. Indecd, the distribution of armour in these ships closely resembles that of the "Canopus," the ehief difference being that in the cruisers there is no barbette or armoured bulkhead for the $\mathbf{9} \cdot \mathbf{2}$-inch guns, which are defended by 6 -inch shields only. In fact, the new first-class battle-ships and cruisers for our own Navy now tend to similarity, both in displacement and armour distribution, but yet there is a wide difference. Speed being the chief essential in cruisers, they must necessarily be of greater length than battle-ships, and it naturally follows that the weight available for armour and guns is so much the less.

\section{CHAPTER -II.}

\section{T'ie Spefo of Cruisers. Machinery anis Bolters. Comer Shearhing. Coal Suplly, and Coni, Ecosomy.}

Though speed is admittedly the most important quality in a cruiser, it is by no mcans the only one, and it is quite out of the question that in any cruiser the offensive and defensive powers should be entirely subordinated to it. 'lo attain very high speed on a continuous run of any distance, such as that across the Atlantic, very large displacement combined with fine lines and ample space for machinery and boilers is an absolute necessity. Consequently, attempts to rival the high speed of the Atlantic liners for long distances, in ships built for war purposes, are fore-doomed to failure.

The following particulars of dimension's, H.P., and speed of the "Terrible" and the "Campania" will illustrate this matter:-

\begin{tabular}{|c|c|c|c|c|c|c|}
\hline Ship. & & 'Length. & Beam. & Draught. & H.P. & Speed. \\
\hline $\begin{array}{l}\text { Terrible ... } \\
\text { Campania }\end{array}$ & $\begin{array}{l}\cdots \\
\cdots\end{array}$ & $\begin{array}{c}\text { Fect. } \\
500 \\
610\end{array}$ & $\begin{array}{c}\text { Feet. } \\
71 \\
65\end{array}$ & $\begin{array}{c}\text { Feet. } \\
29 \\
20\end{array}$ & $\begin{array}{l}25,000 \\
30,000\end{array}$ & $\begin{array}{l}22 \text { (trial) } \\
21 \text { (sea specd) }\end{array}$ \\
\hline
\end{tabular}

While the "lerrible" might manage 22 knots for a spurt on the measured mile, and possibly for an hour or two in shasing an enemy under the most farourable conditions, it is extremely doubtful if she could cross the Atlantic at 19-a voyage which the "Campania" can make with the greatest regularity at a speed of over 21 knots. "To obtain any" considerable increase of speed in future cruisers, apart from what may be gained by improvements in machinery, it would be absolutely necessary to increase the displacement and to build the ships on finer lines. This could only be done by sacrifice of power in offence or defence, including 
strength of hull and water-tight division in the latter category. Increased proportion of length to breadth, if carried too far, would also reduce the efficiency of the ship regarded as a gun platform. Of course, high speed is desirable, but the question is how far other qualities should be sacrificed to it. To answer this question, I propose considering how a cruiser's duties can be more efficiently performed with vessels of increased specd.

Firstly, as regards scouting, that is, watching for and reporting the movements of a hostile flect. Provided the cruiser has, as is now the case, an advantage of two or three knots over battle-ships, she should be quite capable of performing this duty without fear of interference, except by superior cruiser force. An increase in speed then, if attended by loss of power in other directions, would not produce a more efficient scout, as weaker vessels could be more readily driven off by opposing cruisers.

Secondly, as regards chasing and bringing to action the fast ships sent out by an enemy to prey upon our commerce; of course, it is futile to build 20-knot ships only, if our possible enemies build 22-knotters, but it does not by any means follow that the 20-knot ships will be of no value in commerce protection against faster ships. The enemy will not alaug's be ready to steam at his hirhest possible speed, and even a slow ship may sometimes be able to head off a faster opponent, or to turn her towards another of our own cruisers. For efficient commerce protection, numbers are the best defence.

With regard to the attack of commerce, the fast ship, however lightly armed and defended, has the advantage; but commerce attack, in the British Navy at least, should certainly be a very minor consideration.

Our true policy as regards the speed of cruisers, $I$ believe to be as follows :-They should all have sufficient speed to carry out their scouting duties without fear of interference from battle-ships. For this purpose, they should be two or three knots faster than the contemporary battleships, and any' sacrifice must be made to obtain that superiority. It is not our policy to further develop the speed of cruisersebejond the point I have indicated, but we must be prepared, with some ships at least fast and strong enough, to hunt down the most formidable commerce-destroyers built for foreign Navies.

Ability to quickly attain full speed from low is of distinctly higher importance to a cruiser than the power of making long passages at high speed.

As regards the design of machinery, improvements are always taking place, and there is no finality; as I have already argued in the case of battle-ships, the water-tube boiler gives a great tacical advantage to a war-ship, by rendering it comparatively easy to raise steam quickly in emergencies. Anything in the design of engines (such as the double engines on each shaft of the "Blake" and "New York") which is liable to cause delay in getting up full speed from slow, must always be absolutely vetoed. The desirability of three screws instead of two, which is so ably 
adrocated by Commodore Melville, U.S.A., is at present a debatable point. The advantages claimed are greater efficiency; and consequent economy of coal, and a better security against complete breakdown. Against these must be set the need of a larger staff to supervise three separate sets of engines as against two sets, and the increased risk of partial breakdown. To form a just comparison, it would be necessary to have accurate information as to the relative weight of machinery in two ships of equal dimensions, one with three, the other with two propellers, the boilers and engines being of equal efficiency in design and workmanship. It would also be necessary to ascertain the coal consumption and H.P. of both ships at various speeds. I am not aware of any such dato existing at present. As the case now stands, although ships with three propellers have been built for France, Germany, and the United States, we know Sir W. White to be opposed to the change; and it is very noteworthy that the constructors of the Elswick cruisers, who have a free hand as regards new features in design, have not as yet built any ships with three screws.

Should our war-ships be sheathed is a question which must be answered in considering their design as regards speed. The loss of speed due to foul bottoms was a most serious matter in Admiral Cervera's squadron, and has led some authorities to the conclusion that it is better to sheathe all our cruisers at the sacrifice of some fraction of a knot on the measured mile, with a consequent gain in efficiency over unsheathed vessels when kept undocked for lengthy periods. As was pointed out by Admiral Wilson in his remarks on Admiral Colomb's licture on "The Lessons of the Spanish-American War," vessels can only be sheathed at the sacrifice of considerable weight and expense, and the efficiency of the device, as compared with protective compositions, is open to some question. Unsheathed ships are now as a rule docked every six months, and when this course is pursued there is no serious falling off in speed. It is probable that the Spanish vessels had been much longer out of dock than that, and had remained undisturbed at anchor for long periods before the war began-a state of affairs most favourable to the growth of weed and barnacles. There is not much danger of our ships being allowed to get into the state the "Vizcaya" was in at the declaration of war, and I think the Admiralty are now pursuing a correct course in sheathing only a few ships of each class, for service in peace on distant stations, leaving those unsheathed which are intended for the home stations, or reinforcements during war of the distant ones.

In considering the question of coal supply, it will be remembered that our battle-ships are better provided than those of other nations. This, as I pointed out, is a necessity forced upon us by the probable conditions of strategy in future naval wars. An examination of "Brassey's Annual " will show that our cruisers do not possess this superiority over foreign rivals; in fact, they are distinctly inferior to French cruisers of equal size in this respect, as may be seen by the following comparison of typical ships of all sizes in the two Navies:- 


\begin{tabular}{|c|c|c|c|c|c|}
\hline Ship. & & & & Displacement. & Coal Supply. \\
\hline $\begin{array}{ll}\text { Hawke (British) } & \ldots \\
\text { Tage (French) } & \ldots\end{array}$ & $\begin{array}{l}\ldots \\
\ldots\end{array}$ & $\begin{array}{l}\ldots \\
\cdots\end{array}$ & $\ldots$ & $\begin{array}{l}7,350 \\
7, \overline{3} 50\end{array}$ & $\begin{array}{r}850 \\
1, n 00\end{array}$ \\
\hline $\begin{array}{l}\text { Eclipse (British) } \ldots \\
\text { Cécile (French) }\end{array}$ & $\begin{array}{l}\ldots \\
\cdots\end{array}$ & $\begin{array}{l}\ldots \\
\ldots\end{array}$ & $\ldots$ & $\begin{array}{l}5,600 \\
\overline{0}, 933\end{array}$ & $\begin{array}{l}550 \\
940\end{array}$ \\
\hline $\begin{array}{ll}\text { Astraza (British) } & \ldots \\
\text { Aiger (French) } & \ldots\end{array}$ & $\begin{array}{l}\ldots \\
\ldots\end{array}$ & $\begin{array}{l}\ldots \\
\ldots\end{array}$ & $\ldots$ & $\begin{array}{l}4,360 \\
4,352\end{array}$ & $\begin{array}{l}+00 \\
S 60\end{array}$ \\
\hline $\begin{array}{l}\text { Latona (British) } \ldots \\
\text { Bugeaud (French) }\end{array}$ & $\begin{array}{l}\cdots \\
\cdots\end{array}$ & $\begin{array}{l}\cdots \\
\cdots\end{array}$ & $\begin{array}{l}\cdots ! \\
\cdots !\end{array}$ & $\begin{array}{l}3,400 \\
3,740\end{array}$ & $\begin{array}{l}400 \\
5 S 7\end{array}$ \\
\hline $\begin{array}{l}\text { Barham (British) } \ldots . . \\
\text { Coütlogon (French) }\end{array}$ & $\begin{array}{l}\ldots \\
\ldots\end{array}$ & $\begin{array}{l}\cdots \\
\cdots\end{array}$ & ..: & $\begin{array}{l}1,830 \\
1,932\end{array}$ & $\begin{array}{l}1+0 \\
200\end{array}$ \\
\hline
\end{tabular}

The inferiority in coal supply is no doubt compensated by some advantages in other directions, but a little consideration will show that the marked superiority of the French ships in this respect is the direct outcome of the anticipations formed of the probable course of a naval war between the two countries, and that the French have pursued a correct course in giving their cruisers, as distinguished from battle-ships, a very large provision of coal by a sacrifice of other qualities. In the French Navy, commerce attach is a primary consideration, and owing to the comparatively small number of French coiling stations, a large coal supply is imperatively necessary for their cruisers to succed as commercedestroyers, and must be provided for at the expense of other qualities. Though a large coal supply is not so vitally important for British cruiscrs, they must be at least aeell provided, and should be capable of taking in a large extra quantity in cases of emergency, the coal bunkers being made larger than necessary for normal supply for this purpose. The bunkers of the "Cressy" and "Drake" class are designed to this end. Some of the second-class cruisers in the British Navy have not, I consider, a sufficient supply of coal.

Intimately connected with the question of coal supply is that of coal economy. It will always be more adrantagcous to be able to sare coal by efficient-design of machiuery and boilers than to carry a large supply. The question of coal consumption in water-tube boilers has been discussed in Part I., Chapter IV., and what was there written applies cqually to cruisers and bittle-ships.

\section{CinApter III.}

The: Offrasiff Powers of Crutraks, Guns, lokpenofs, and Rans.

Cruisers not being intended to engage with battle-ships, their gun armament should be d:signed almost exclusively for the purpose of defeating other cruisers. The experience of the recent wars has shown very conclusively that vessels with unarmoured batteries can be more 
easily' put out of action by shell-fire clirected against guns' crews and unarmoured parts than by attack of the water-line or machinery. For an action against a ship whose only protection consists of an armoured deck or a narrow water-line belt, the most effective armament would be a large number of the smallest guns capable of exploding common shell in the enemy's batteries, provided only that the shell be large enough to produce serious incendiary effect. However, it is extremely improbable that any cruiscrs will be built in future destitute of all protection to their batteries, and it would therefore be unwise to reduce the size of the guns to the extent indicated in the last paragraph, as, however formidable such a ship might be to the second-class cruisers now afloat, she would probably be no match for a ship of her own date having moderate armour on the battery. The armament must, of course, be proportioned to the size of the cruisers, and it will therefore be well to consider separately the three classes.

In the latest projected first-class cruisers for the British Navy the armament is as follows:-

Cress'. $-12,000$ tons; two $9 \cdot 2$-inch, twelve $B$-inch, and seventeen smaller.

Drake.-14,100 tons; two 9-2-inch, sixteen 6 -inch, fourteen 12pounders, and three 3 -pounders.

New class of 9,800 tons; fourteen 6 -inch, ten 12-pounders, and three 3-pounders.

For attack of unarmoured parts, the $9 \cdot 2$-inch has little or no advantage over the 6 -inch, as, though it would cause heavier damage, it cannot be fired so quickly; but it would certainly be unwise to limit the armament of our cruisers entirely" to one sized gun, for such a course would undoubtedly simplify the question of the application of armour for the enemy's ships. The desirability of mounting a small proportion of comparatively heavy guns is also much increased by the tendency of the present day to introduce hard-faced armour, about six inches thick, for the defence of batteries, etc.

I would suggest that certain advantages might be gained, if instead of placing the $9 \cdot 2$-inch guns as at present, they were both mounted in a single barbette aft in a similar manner to the 12-inch guns of the "Majestic." with this exception, viz., the after bridge and superstructure in the cruiser, should be abolished or confined to a narrow limit on the centre line; this would admit of the barbette guns being trained well before the beam, like the guns of the "Dreadnought" and "Thunderer." $\mathrm{My}_{\mathrm{y}}$ reason for suggesting this is as follows. When in chase of an enemy, it may be presumed that that enemy will generally be of inferior force and ill-protected with armour, consequently in such a case the $9 \cdot 2$-ijsch gun would possess no advantage over the 6-inch. The circumstance may frequently arise that a battle-ship would be detached to drive off an enemy's cruiser observing the movements of the fleet. In such a case the cruiser would be obliged to turn her stern to the battle-ship, and the two $9 \cdot 2$-inch guns would be invaluable. By reducing the superstructure before the guns the arc of training would be very inuch increased, and 
the guns would be able to do their fair share of broadside fighting in a cruiser action.

To complete the alteration of armament, the two after 6 -inch casemates on the upper deck in the "Cressy" should be omitted, and replaced by two 6 -inch gins in a turret on the forecastle, where the $9 \cdot 2$-inch is now mounted. The 6 -inch gun forms the main armament of all our first-class cruisers, and to this end it is admirably adapted for the following reasons. The projectile of 100 lbs. weight can be easily man-handled. A gun of greater calibre, if constructed of the proper proportionate length to fully develop its powers, would be too long to he conveniently mounted on the broadside. Under present conditions the 0 -inch gun is sufficiently powerful for the work demanded of it, also the 6 -inch gun having been universally adopted for the secondary armament of battle-ships, its use in cruisers by avoiding multiplicity of types simplifies such questions as the supply of ammunition, the improvement of details of mechanism. and the training of our scamen In view of the increased area protected in new ships by moderate armour, it would certainly be unwise to reduce the calibre of the principal armament in any class of cruiser. Indeed, however undesirable it may be, it is quite possible that an increase of calibre may be forced upon us by improvements in the quality and disposal of armour in future ships of foreign Powers.

Whatever improvements in armour the future may bring forth, it is improbable that cruisers can ever be constructed without some parts unarmoured, and therefore vulnerable to very light guns. For the attack of these the 12-pounder now mounted is admirably adapted, as also for repelling torpedo attack.

With the exception of the modification I have suggested in the placing of the $9 \cdot 2$-inch, I consider the arrangement of the guns in the "Cressy" class to be admirable for the purpose for which they are intended.

Since the six ships of the "Cressy" class and the four "Drakes." were laid down, two new cruisers of 9,800 tons have been projected. As regards gun power they are inferior to the "Cressy." mounting fourteen 6 -inch against two 9-2-inch and twclve 6 -inch. They are also armoured more lightly. The guns are to be mounted four in turrets and ten in casemates. It is not quite clear what are the particular functions of this type, as they must undoubtedly be much inferior in power to their predecessors, the "Drake" and "Cressy", but yet they are too large and powerful to be consigned to the second class. With regard to their armament, I think the two turrets should certainly be provided with 8 -inch guns in place of 6 -inch, and that to this end a slightly increased displacement should be allowed. My reasons for suggesting this are, that in view of the improvements of armour, all cruisers of the first class should have a small proportion of comparatively heavy guns. When guns are mounted in a turret on the centre line, the great objection to increased length, which holds in the case of the broadsicle gun, disappears. Indeed, in a turret gun increased length is a positive advantage, because the muzzle of the gun being nearer to the ship's side, there is less risk of damage to the dech and other structures of the ship by the blast from her own guns. 
I now come to the armament of second-class cruisers, and here I may remark there is no new design in the British Navy to criticise. We have large numbers of second-class cruisers completed, but none under, construction. A halt seems to have been called for the present, probably to await the development of the armour-plate industry, as it is improbable that even second-class cruisers will in future have their guns so entirely unprotected as in the past. Hitherto the armament of our second-class cruisers has consisted principally of the $4 \cdot T$-inch guns supplemented by 6 -inch guns mounted forward and aft. This arrangement was, I think, a wise one, because at the time these ships were designed there was no question of their being called upon to attack any vertical armour. In the three latest completed ships, the "Hermes," "Hyacinth." and "Highflyer," howerer, the armament is eleven 0 -inch guns, six of these having been substituted for the six $4 \cdot 7$-inch in former ships of the same class. This alteration is doubtless attributable to the impending introduction of vertical armour for ships of this size. What the designs of future second-class cruisers in our own Service may be, it is impossible to anticipate with certainty; but as they will inevitably be called upon to meet ships protected with moderate armour, their armament will probably have to be increased in power. The demands for increased armour and armament will certainly cause some increase in displacement, and the second-class cruiser of the future will probably be a vessel of not less than 6,500 tons. I would suggest as a suitable armament two 8-inch guns in a turret aft, like the Japanese "Asama," two 6-inch in a similar turret forward, and six 6-inch in casemates on the upper deck, also a large number of 12-pounders for the altack of unarmoured vessels.

With regard to the supply of ammunition, our cruisers have the same allowances as the battle-ships. This I believe to be more than an adequate supply, for it can hardly be supposed that cruisers will be able to sustain such lengthy and hard-fought actions as battle-ships, andi $I$ think some reduction might be made in the allowance with perfect safety. To recommend reductions in any direction is certain to arouse opposition, and the weight which could be saved may appear insignificant; but $\mathrm{I}$ am sure that the only way to obtain the most efficient possible vessel for a given displacement is to encleavour to save weight wherever it can be done without impairing fighting efficiency.

'The gun armament of the third-class cruisers must necessarily be light, and at present there is no question of their being required to attack armour in any case. 'Their armament should, I think, consist largely of 12-pounders on the broadside, supplemented by from two to four $4 \cdot 7$-inch guns as bow and stern chasers.

Torpedors and Rams.-Experience in the late Spanish-American war has conclusively proved the extreme danger of torpedoes in above-water tubes between decks; whether the "Vizcaya's" torpedo was exploded dirctly' by shell fire, or indirectly by the fire caused by the shell spreading to the torpedo, is immaterial ; the above-water tube befiven decks in all ships is inadmissible; such torpedocs as are provided in first and second-class cruisers must be submerged. In third-class cruisers weight will probably 
preclude the submerged tube, and torpedo-tubes, if provided, must be on the upper deck; the danger of explosion will not be so great in this case as with a tube between decks, where serious fires are more likely to occur, also the torpedo not being in a confined space, such great structural damage would not occur as was the case with the "Vizcaya." My own opinion is that first and second-class cruisers should have two submerged torpedo-tubes fixed in training on the bow, and third-class cruisers two tubes on the upper deck, also on the bow; there should, I think, be two torpedoes for each tube, or four for each cruiser, and no more.

All cruisers should also be fitted with ram bows, strengthened as far as the size of the ship will allow.

I do not anticipate that either ram or torpedoes will often play a prominent part in actions between cruisers, as I think these will nearly always be decided by the gun; but I believe that opportunities will occur in war, in which ships will find themselves in the presence of an unquestionably stronger enemy without hope either of escape or successful gun action. Under these circumstances they may, while sacrificing themselves, do most invaluable service for their country by means of the ram and torpedo. Such an action was certainly the only true course open to the Spaniards at Santiago. With absolute choice of the time of action, they might have issued from harbour at dusk at full speed, and fully prepared, and with determination might have inflicted very great injuries on their foes, instead of striving only for an ignominious escape. In this case, no doubt, the result of the war would not have been for long affected; but suppose only a detachment of a fleet or a few cruisers in Admiral Cervera's predicament, what an immense advantage might be gained for the side if even one battle-ship were disabled or sunk before the defeat of the detachment was accepted.

In the old days of wooden ships there was practically no object in fighting against overwhelming odds-the sloop could not hope to effect any damage against a line-of-battle ship, whatever sacrifice was made, but with the battle-ship and third-class cruiser the case is different. The latter, if escape is impossible, can always try to torpedo or ram the enemy, and even if destroyed in the attempt without effecting any damage, the enemy will not have gained a third-class cruiser in good order to turn against her own side. What might be done in such a case was well demonstrated by the " Pactolus." when captured by cruisers of " B". Fleet in the late mancuvres. The half hour that was necessary to put her out of action, in accordance with the rules, was spent in manouvring for opportunities of torpedo attack; and had it been real war, if the torpedoes failed, a determined captain would have done his utmost to use the ram.

\section{Chapter IV.}

\section{Defensive Properties of Cruisers.}

Armour Protection.- The weight which it is possible to devote to armour protection must be limited as compared with that of a battle-ship, 
and, however desirable, it is evidently impossible to defend all points so well as we might wish. Risks must be run in war, and it is an impossible task to secure a ship against them all. The points we have to consider in the armour design of every ship are:-

1. The duties she is intended principally to perform.

2. The gun attack she is likely to meet in performing those duties.

3. How best to dispose of the weight available for armour, in defence against that attack.

Attacking battle-ships is not the purpose of cruisers; whatever their class, though occasions may sometimes arise when action with them will be unavoidable. The gun attack then to be considered should not include that' of battle-ships, but does undoubtedly comprise that of all cruisers in possibly hostile fleets.

For example, in the French Navy there is now building a class of 10,000-ton armoured cruisers, of which the "Gloire" is an example, the principal gun armament being as follows:- Two $7 \cdot 6$-inch, eight $6.4-$ inch, six $3 \cdot 9$-inch, the perforations of wrought-iron at the muzzle being 23.7 inches, 20.0 inches, and 14.3 inches respectively. In the German Navy the "Fürst Bismarck" is provided with four 9.4-inch, twelve $5 \cdot 9$-inch, ten $3 \cdot 4$-inch, having perforations at the muzzle of $40 \cdot 9$ inches, $25 \cdot 9$ inches, and $12 \cdot 6$ inches. The perforations quoted are the maximums of the newest patterns under most favourable conditions at the proving ground, and such good results are not likely to be obtained after the guns have been in use any time. The calculated perforations fall very rapidly with the range, so that at 2,000 yards the heavy guns would perforate less than three-quarters, and the light guns less than two-thirds their muzzle perforations. The recent great improvements in armour made by Harvey and Krupp have produced 6 -inch plates which are capable of withstanding A.P. shot better than would twice their thickness of wrought-iron. Their bchaviour against shell, common and armour-piercing, cannot be so accurately stated; but as the strength of the hard-faced plate lies in its power to break up projectiles, it is certain that they more than retain their superiority over wrought-iron against this form of attack. A 6-inch Krupp plate may' safely be considered proof against any common shell at moderate range. Improvements will undoubtedly be made in armourpiercing shell, and the device of capping them with wrought-iron generally introduced, but it is not likely that a penetration approaching that of the A.P. shot will be obtained. The A.P. shell does not carry so large a bursting charge as the ordinary common, and, therefore, when it bursts inside a ship does not effect so much damage.

The muzzle perforations quoted above appear at first sight so great that it would seem almost hopeless to defend against them. Taking the greatest of all, the Krupp $9 \cdot 4$-inch, which perforates $40 \cdot 9$ inches at the muzzle under most favourable conditions, this at 2,000 yards would not be more than 30 -inch iron, or, say, 14 -inch Krupp steel. We see, therefore, that the 6-inch Krupp plate would be useless as a defence against the shot, but it is more than probable that it would defeat any shell yet produced for 
the same gun. Taking again a gun capable of perforating 21 -inch iron at the muzzle, at 2,000 yards such a gun would only git through about 8 inches of Krupp steel with A.l'. shot, so that it would be necessary to strike a 6 -inch plate nearly normally to defeat it. Kirupp armour has entirely changed the conditions as regards the armouring of cruisers. $A$ few years ago vertical armour, to be of practical value, had to be so thick that its use in a cruiser was either out of the question, or only possible over a very small area, consequently the use of vertical armour was practically abandoned in farour of the armoured deck, which, as it necessarily presents a very inclined surface to the line of fire, could afford very efficient protection to the machinery and lower parts of the ship with a comparatively small thickness; efficient defence as the armoured deck is for what it was designed, it is of no aval against the effects of shell fire on the upper works. On the other hand, the armoured deck possesses the great advantage over vertical armour of increasing the structural strength of a ship. . This was very noticeable in the effect: of the magazine and torpedo explosions on board the Spanish ships at Santiago-the armoured decks in all the cruisers rimaining unbroken; also its prese.uce in any ship is a great danger to an encmy ramming, as was well shown by the damage done to the bows of the "Camperdown" in her collision with the "Victoria."

The great importance which has been shown at the battles of Yalu and Santiags of defeating shell attack as far as pjosible, adled to the improved quality of armour plates, is now very rightly bringing about a greatly extunded use of vertical ar.nour in all ship;, cruisers, and b.utleships alike. Hithero in the British Navy we have not protect:d any cruisers with an area of vertical armour equal to that of the "Duplay di Lome,"-or the Italian cruisers of which th: "Co.on" was a type, but in the "Cressy" a large proportion of the ship's side is armour-plated with 6 -inch plates, the armourcd deck two or three inches thick, however, being still retained.

In disposing armour to the best advantage, besides considering the gun attack to which the ship is liable, it is also ncecsary to arrive at the relative importance of def nnce of the various points, in order that each may be assigned its due proportion of available protection. For instance, if the main engines were disabled in.action, it would be a more disastrous matter than a big hole between wind and water, which latter injury would be more serious than the destruction of a gun and its crew. Of the inachinery, the cylinders of the main cngines are most open to attack, and damage to lhem would have the most serious results; boilers, on the other hand, can be placed low, and the chances of their being struck are small, though if they are hit the consequences must be very serious. The water-line must always be difficult to strike, as it does not offer a target with any appreciable vertical height; the consequences if it is struck though, would only ba less serious than damage to machinery. The guns and their crews offer a better target than either of the foregoing, but the effect of a gun being put out of action should be considurably less important. : The conning-tower containing the steering wheel and telegraphs is a most important point to be defended. 
In the "Cressy" and "Drake" classes all these considerations appear to have had due importance attached to them. $A$ belt of 6 -inch Krupp steel terminated by $\tilde{0}$-inch bulkheads, forms a citaclel in the central part of the ship. This belt armour has a vertical height of 11 feet 6 inches, and thus protects the most important part of the water-line against all shell fire, and in connection with the armoured deck defends the machinery and boilers against A.P. shot, except those of the largest size. The armoured deck, which is two to three inches in thickness, rises from the lower edge of the belt armour as in the "Majestic." The armoured deck is continued from the ends of the belt armour to the bows and stern, and thus in conjunction with water-tight sub-clivision affords good protection for buoyancy and stability. Forward of the belt armour the side is protected by 2 -inch nickel steel as in the battle-ship " Formidable"; the whole of the water-line except 90 feet at the stern is thus proof against the lighter Q.F. guns. The 6-inch guns are well defended in 6-jnch Krupp steel casemates, and their ammunition supply is protected by the citadel armour. The $9 \cdot 2$-inch guns are provided with 6 -inch lirupp shields. It will be seen that the armour has been applied on similar lines to that of the battle-ship "Canopus"; in fact, the design of the two ships in every way is very similar, and the "Cressy" may be said to be a ship of the "Canopus" class, in which the heavy 12-inch guns and the 12-inch barbette armour have been sacrificed for the sake of $2 \frac{3}{4}$ knots in speed. In the previously-built cruisers "Terrible" and "Diadem" the gunarmour is almost identical with that of the "Cressy," but there is no vertical belt, the sole protection to machinery and flotation consisting of the armoured deck. The addition of vertical belt armour in the "Cressy" was, I consider, a most necessary improvement in view of recent. experience, but, I think, having committed ourselves to the adoption of side armour for first-class cruisers, the retention of the armoured deck in its present form, in addition to the side armour, calls for some consideration. That there should be an armoured deck throughout the entire length of the ship, meeting the lower edge of the belt armour at the ship's side, and rising amidships, is certainly most desirable, but all parts of the ship are not of the same importance to defend, and I believe that general efficiency would be promoted by a reduction of thickness of the deck within the citadel, except the part over the cylinders and engine-room, where it might be somewhat increased. As I have already pointed out, we must not attempt to protect cruisers against the attack of battle-ships, and if we are to maintain a good superiority of speed we must not be led into over-weighting them by the endeavour to render them invulnerable.

Second-class cruisers hitherto have been practically destitute of all vertical armour protection in the British $\mathrm{Navy}$, but it is probable in future designs this will be no longer the case, and that a large proportion of the weight available for armour will be utilised in the defence of the gun positions. It is probable that the displacement of second-class cruisers will have to be considerably increased to meet the demand of protection for the gun positions, but the use of vertical armour on other parts can hardly be warranted under present conditions, 
In my opinion, the armour protection required for a second-class cruiser of about 6,000 tons is as follows :-

Armour deck to a thickness of 4 inches on the slopes, and 2 inches on the flat over cylinders; in other parts, 1 inch on the flat and 3 inches on the slope. Casemates and turret armour for 6 -inch and 8 -inch guns, 4 to 6 inches in thickness. Conning-towers 6 inches. No bulkhead or belt armour.

In third-class crinisers the deck protection should be proportionally thinner, and the only gun protection should be that afforded by small and thick shields over the breeches of the guns. The guns, which would, of course, all be on the upper deck, should be masked as little as possible by thin plating, which can only serve to burst shell amongst the men serving the guns.

The coal bunkers in a cruiser, as in a battle-ship, should be placed so that the coal can be readily brought to the furnaces, and quickly stowed in the bunkers. These conditions fulfilled, the bunkers may with, great advantage be arranged to afford additional protection to machinery and boilers against A.P. projectiles which might pierce the armour deck. Water-tight sub-division is at least equally important to cruisers as to battle-ships, and there is no occasion to add anything to what has been said on this subject in Part I., Chapter I.

The remarks in Part I., Chapter IV., on fires in action and their cxtinction, and the desirability of limiting the weight of fittings and stores as far as possible, apply with even greater force in the case of cruisers.

The cruiser being less well defended against shell attack, is necessarily more liable to fire; the use of wood is therefore more undesirable than in a battle-ship.

Agrain, to save weight in a vessel built for speed is far more important than in a battle-ship built chiefly with a view to strong offensive and defensive powers.

\section{PART III.-TORPEDO-VESSFLS.}

\section{Chapter $\mathrm{I}$.}

Torpedo attack anil Defence. Torpedo-Gunboats, TorpedohOATS, AND TORPEDO-BOAT DESTROYERS.

Excepting the attacks by the Japanese on the defeated and demoralised Chinese fleet at Wei-hai-IVei, nothing of importance was achieved by torpedo-boats in the late'wars. It would be rash, however, to unduly depreciate the danger of torpedo attacks on that account. The danger is a very real one, as all those who have taken part in naval mancuvres are well aware. To sink a rapidly moving torpedo-bcat on a dark, wet night will be no easy task, though the gumers be the best in the world, and it is now justly recognised that the truest defence is to prevent, if possible, the boats coming within range of the battle-flect at all. When the fleet is at anchor, it is now the intention that they should generally lie in security in some specially prepared harbour, such as Portland or Gibraltar. 
When this is not possible, nets will be used, although these are by no means a perfect defence against torpelo attack. At sea, torpedo nets are impracticable, and the best known method of keeping boats at a distance is to oppose them with a large number of boats of greater speed and gun-power.

As the leading naval Power, it is very much more important to England to be strong in defence against torpedo attack than to be prepared with large numbers of boats for the attack of the enemy's fleet; but the attack on this account must not be entirely neglected, as that would at once give our enemies an undue advantage by increasing their liberty of action.

Ten years ago the defence was provided for by large numbers of the torpedo-gunboat class, and the attack by torpedo-boats of 120 to 130 feet length; the former had a sea speed of not more than 18; the latter about 19, knots. The torpedo-gunboat class is perhaps the most conspicuous failure of recent years. Built for the sole purpose of destroying torpedo-boats, they had not sufficient speed to overtake them. Their failure was probably due to the fact that too much was demanded in their design. The attempt was made to make them entirely selfsupporting, seit-going vessels, and the weight to be carried for this purpose necessitated so great a proportion of breadth and draught to length that really high speed was unattainable. The torpedo-boats built at the same time were too small to have very good sea-going qualities, but they were much more efficient for the purpose for which they werc built than werc the torpedo-gunboats.

In the torpedo-boat destroyers built during the last six years, we have a really good class of torpedo-vessel-much more efficient to perform the defensive duties for which the torpedo-gunboat was built, and at the same time very much faster and with better sea-going qualities than the torpedo-boat proper. Destroyers are really sea-goingr torpedoboats of increased size and speed, armed primarily with guns for the destruction of the enemy's boats, but also provided with torpedoes for usc against the enemy's ships, should opportunity occur. They have now completely supplanted the torpedo-gunboat and torpedo-boat in the British Navy, and the remainder of this part of the essay will be devoted to a discussion of their requirements.

\section{Chapter il.}

Requirements of Torpedo-boat Destroters; Speed, Manceuvina and Sea-going Powne, Armanest, and Defensive. Power.

Destroyers must necessarily have sufficient speed to overtake any of the torpedo-vessels built for foreign Navies. To obtain this very high speed, the engines must therefore be of very great power, and of very light weight in comparison. The boats must be built on very fine lines, and the hulls constructed as lightly as is compatible with safety. The weight to be carried must be as small as possible, and everything that is not absolutely necessary dispensed with. All these considerations are VoL, XLIV. 
against the vessels being capable of undertaking long independent cruises; but that is not their purpose, and that power is necessarily sacrificed to enable them to cruise for short periods with a very high speed always at command. The following table gives the dimensions, H.P., speed, and coal capacity of a few typical destroyers :-

\begin{tabular}{|c|c|c|c|c|c|c|c|}
\hline \multirow{2}{*}{ Name. } & \multicolumn{4}{|c|}{ Dimensions. } & \multirow{2}{*}{ H.P. } & \multirow{2}{*}{ Speed. } & \multirow{2}{*}{$\begin{array}{l}\text { Coal } \\
\text { Supply }\end{array}$} \\
\hline & Length & Beam & Draught & $\begin{array}{c}\text { place- } \\
\text { ment }\end{array}$ & & & \\
\hline $\begin{array}{ll}\text { Havock, } 93 & \ldots \\
\text { Ardent, } 91 & \ldots \\
\text { Desperate, } 95 & \ldots . \\
\text { Erane, } 96 & \ldots \\
\text { Express, } 97 & \ldots\end{array}$ & $\begin{array}{l}\mathrm{Ft} . \\
180 \\
201 \cdot 6 \\
210 \\
215 \\
227 \cdot 8\end{array}$ & $\begin{array}{l}\mathrm{Ft} . \\
18 \cdot \overline{5} \\
19 \\
19 \cdot 8 \\
20 \cdot 7 \\
22 \cdot 0\end{array}$ & $\begin{array}{l}\text { Ft. } \\
5: 25 \\
7 \cdot 3 \\
7 \cdot 2 \\
6 \cdot 8 \\
0\end{array}$ & $\begin{array}{l}\text { Tons. } \\
240 \\
247 \\
275 \\
3: 4 \\
300\end{array}$ & $\begin{array}{l}3,500 \\
4,500 \\
5,800 \\
6,336 \\
7,700\end{array}$ & $\begin{array}{l}\text { Knots. } \\
26 \cdot 77 \\
27 \cdot 97 \\
30 \\
30 \cdot 3 \\
33\end{array}$ & $\begin{array}{c}\text { Tons. } \\
57 \\
80 \\
80 \\
80 \\
80\end{array}$ \\
\hline Viper, $99^{3}$ & 210 & 21 & 7 & $312\}$ & $\left\{\begin{array}{c}- \text { to } \\
10,000\end{array}\right\}$ & 31 to 35 & 88 \\
\hline
\end{tabular}

18 propellers driven by Parsons' steam turbines.

It will be seen from the above that the chief increase has been in H.P.; the earlier boats were designed for 27 knots, but.by a moderate increase in displacement and a large increase in H.P. 30 knots and over have been obtained on the trial trips in all boats built since 1895 .

The engines of destrojers are being continually improved with a view to obtaining better results without increase of weight, and there can be no doubt that future improvements will develop still further the high speed of the present boats. Parsons' steam turbine shortly to be tried in the "Viper," may possibly revolutionise the machinery design for torpedovesscls. This engine certainly seems to be most almirably suited for use in destroyers, but it is probable that, as with all new departures, there will be many difficulties to overcome before permanent success is attained. Water-tube boilers are an absolute necessity in destroyers to obtain the high power required, with a small expenditure of weight and space.

The full-speed contractor's trials of destroyers are now carried out with lighter loads on board than would usually be carried by the boats on service. The builders are thus cnabled to produce very high speeds on the measured mile, which cannot be maintained under ordinary conditions afterwards. This is well known, and the paper speeds are discounted accordingly, but $I$ think it is a vicious procceding which should be discontinued for the following reason :-The builder's aim being to produce a good result at the trial trip, and to better his rivals by some fraction of a knot, he will naturally design the form and lines of his boat, and the propeller and engines also, to give the very best result at the light draught, and will disregard her performance when loaded down to service conditions. Nothing could be worse than this, and I consider that all trials should be carricd out with all equipment and stores on board, and these placed in their proper service positions, no trimming of the 
Weights being allowed to produce better speed on the measured mile. The builders would then be compelled to design with a view to good results on service conditions, and though there would be a falling of in the paper speeds, the reliable sea speed would probably be increased. This course would also tend to limit the weight of equipment and stores to what is strictly necessary for service conditions. It cannot be too clearly laid down that the amount of weight carried is a most important factor as regards speed, and that hull, boilers, machinery, armament, and equipment, etc., should not be a ton heavier than is necessary.

It is most important that destroyers should have the power to turn rapidly in a comparatively small space, as much of their work will be carried out in narrow waters; good turning powers will also assist them greatly in their task of hunting down torpedo-boats. There is no reason to complain of the present boats in this respect.

Although not required to make very long independent voyages, destroyers should be at least able to keep the sea in all ordinary weathers, so the strength of hull and all fittings should be designed accordingly. Such small vessels must necessarily be very lively in any sea, and therefore bad gun platforms; anything that can be done to improve them in this respect by disposition of weights, or other means, is most desirable. The use of bilge kecls would, no doubt, do some good, but would unfortunately reduce the speed at the same time.

Destruction of the enemy's boats being the chief object of these vessels, guns must necessarily be the first consideration in their armament, which now generally consists of one 12-pounder, five 6-pounders, and two torpedo-tubes. This armament is probably amply sufficient. A very large supply of ammunition should not be allowed, the boats replenishing their supplies when necessary from ships or other sources. Although the gun armament should be the first consideration, each destroyer should carry at. least two torpedoes. Without torpedoes the boats would be at the mercy of any smail cruiser they might encounter, and, while watching the ports of an enemy for the escape of torpedo-boats, opportunities will often occur for torpedo attack. The destroyers are now supplied with 18-inch torpedoes, which are, of course, superior in range, speed, and destructive power to the 14-inch pattern. Considering, however, the paramount importance of reducing weight, and that very good torpedoes can be made of the smaller size, the wisdom of providing the larger is, to say the least, a debatable point.

Armour protection is, of course, quite out of the question for destroyers on account of its weight, but they should be protected to some extent against sinking by water-tight bulkheads, which will at the same time increase the structural strength of the boats. The coal bunkers should always be arranged to give as much protection as possible to boilers and engines.

\section{Coxclusion.}

In the subject of this essay we are asked, What are the best types of war-vessels for the British Navy? 
In the foregoing chapters, though a definite answer may not have been found to this question, I have endeavoured to cstablish that:-

1. Apart from increase of power due to new inventions and the improvements dictated by experience, the total force (offensive, defensive, and motive) of every war-vessel is directly dependent on her displacement. From this it follows that an increase of power in one of the three qualities entails a loss of power in one or both of the other two, provided always that the displacement be not increased.

2. In the design of every vessel the duties she is intended for should first be well thought out, and the proper relative importance be attached accordingly to each of the three fighting qualities.

3. Attempts to combine the highest possible efficiency of all threc qualities in one ship would necessitate dimensions hitherto unheard of, or, if the present dimensions were adhered to, would result in incvitable failure. In short, we should not try to build battle-ships capable of steaming so fast as cruisers, nor cruisers which could sustain the gun attacks of battle-ships.

4 To recommend desirable additions to fighting strength, increased power of machinery, or large supplies of ammunition and coal in any ship, is a comparativcly easy task; but to point out what can be omitted without risk is a very difficult one. NIany things are now supplied to our ships which can have no influence on their fighting powers, but all of which might be useful under some conditions. All of these have a certain weight, and if any of them could be dispensed with, fighting power or speed might be increased to a corresponding degree without increase of displacement. Opinions will naturally differ on the proper importance. of the articles I refer to, but $I$ believe there is room for no small reduction without impairing efficiency; and that it is quite as important that designers should know what can be safely and profitably onitted as that they should know what it is necessary to provide.

We are not asked to consider in any way the numbers of ships required in the British Navy; but, since there must be some limit to tine total force which a country should be called upon to provide, the ques. tion arises, Should the total force consist of a large number of small or moderate-sized ships, or a smaller number of greater size ?

I propose to conclude my essay by an endeavour to answer briefly this question-firstly, with regard to battle-ships, and, secondly, with regard to cruisers.

The chief advantage of distributing the total force of the battle-flect in a comparatively large number of moderate-sized vessels is, that if one or more of the fleet be put out of action by ram or torpedo, the loss 
would be relatively less than if the feet consisted of a smaller number of larger ships. On the other hand, the essence of success in fleet actions lies in concentration of force, and it is plain that this concentration can be better effected with a small number of very powerful ships than with a larger number of less powerful ones.

Again, suppose two fleets of equal total tonnage and equal speed and coal endurance, but one consisting of moderate-sized ships, the other of a smaller number of larger ships, and that the two fleets mount guns in equal numbers and of the same power, the area of armour necessary to defend the fleet of small ships will be greater than the area necessary to defend the fleet of largi ones; consequently. the armour of the small ships must be thinner than that of the large ones, or parts which are armoured in the large ships must be left unprotected in the small. In either case, the flect of small ships must be less well defended. It may be shown in the same way that if the ships are equally well defended, either the gun-power or speed of the fleet of small ships will suffer by comparison with the large. Though the small ships have the advantage against torpedo-boats, I consider the balance of advantage lies with ships of larger displacenent.

The case of cruisers is quite different. For the efficient performance of their duties of scouting and commerce protection, it is essential that the total force should be distributed in a large number of ships. Their displacement cannot, of course, be reduced beyond certain limits, as it is impossible to obtain a really fast sea-going cruiser of small dimensions, and while foreign nations build very large and powerful ships, it is imperative that we should also have some capable of meeting them on equal terms. As cruisers of whatever size are very much more vulnerable by gun attack than battle-ships, it foilows that a small cruiser need not be at such great disadvantage, compared with a large one, as a small battle-ship would be in action with a big one. $\mathrm{My}$ opinion is that a sufficient number of first-class cruisers should be built strong enough to deal with all those built and building for possibly hostile fleets, and that besides these, second and third-class cruisers should be constructed of moderate dimensions, and in sufficient numbers, for the scouting and commerce-protection duties they will be called upon to perform. 